Article

\title{
Conceptual Design of Operation Strategies for Hybrid Electric Aircraft
}

\author{
Julian Hoelzen ${ }^{1}$, Yaolong Liu ${ }^{2, *}$ (D) Boris Bensmann ${ }^{1, *}$, Christopher Winnefeld ${ }^{1}$, Ali Elham ${ }^{3}$, \\ Jens Friedrichs ${ }^{4}$ and Richard Hanke-Rauschenbach ${ }^{1}$ \\ 1 Institute of Electric Power Systems, Leibniz Universität Hannover, Appelstr. 9a, 30167 Hanover, Germany; \\ julian.hoelzen@kabelmail.de (J.H.); christopher.winnefeld@ifes.uni-hannover.de (C.W.); \\ hanke-rauschenbach@ifes.uni-hannover.de (R.H.-R.) \\ 2 Aeronautics Research Centre Niedersachsen (NFL), Technische Universität Braunschweig, \\ Hermann-Blenk-Straße 42, 38108 Braunschweig, Germany \\ 3 Institute of Aircraft Design and Lightweight Structures, Technische Universität Braunschweig, \\ Hermann-Blenk-Straße 35, 38108 Braunschweig, Germany; a.elham@tu-braunschweig.de \\ 4 Institute of Jet Propulsion and Turbomachinery, TU Braunschweig, Hermann-Blenk-Straße 37, \\ 38108 Brunswick, Germany; j.friedrichs@ifas.tu-bs.de \\ * Correspondence: yaolong.liu@tu-braunschweig.de (Y.L.); boris.bensmann@ifes.uni-hannover.de (B.B.); \\ Tel.: +49-531-391-66662 (Y.L.); +49-511-762-14404 (B.B.)
}

Received: 15 December 2017; Accepted: 12 January 2018; Published: 16 January 2018

\begin{abstract}
Ambitious targets to reduce emissions caused by aviation in the light of an expected ongoing rise of the air transport demand in the future drive the research of propulsion systems with lower $\mathrm{CO}_{2}$ emissions. Regional hybrid electric aircraft (HEA) powered by conventional gas turbines and battery powered electric motors are investigated to test hybrid propulsion operation strategies. Especially the role of the battery within environmentally friendly concepts with significantly reduced carbon footprint is analyzed. Thus, a new simulation approach for HEA is introduced. The main findings underline the importance of choosing the right power-to-energy-ratio of a battery according to the flight mission. The gravimetric energy and power density of the electric storages determine the technologically feasibility of hybrid concepts. Cost competitive HEA configurations are found, but do not promise the targeted $\mathrm{CO}_{2}$ emission savings, when the well-to-wheel system is regarded with its actual costs. Sensitivity studies are used to determine external levers that favor the profitability of HEA.
\end{abstract}

Keywords: hybrid electric aircraft; overall aircraft design; propulsion design; battery strategy; regional aircraft; wingtip propellers

\section{Introduction}

In recent years, there has been increased attention towards new and more efficient technologies in the aviation landscape. The European Union (EU) Commission, aviation related member organizations and industry players created a vision, the Flightpath 2050, for future research agendas in this field. All of these members agreed to reduce global carbon dioxide $\left(\mathrm{CO}_{2}\right)$, nitrogen oxides $\left(\mathrm{NO}_{x}\right)$ and noise emissions. In 2050, aircraft should pollute $75 \%$ less $\mathrm{CO}_{2}, 90 \%$ less $\mathrm{NO}_{x}$ and $65 \%$ less noise [1]. The percentages are related to a reference emission scenario in the year 2000 . This is challenged by a tremendously increasing air transportation demand [2,3].

These goals shall be mainly achieved by increasing aerodynamic and propulsion system efficiencies, but also by optimized Air Traffic Management (ATM), infrastructural operations and non-infrastructure related airline operations. Many research initiatives tackle this challenge and analyze new propulsion concepts for aircraft. Most authors identify the battery as the main critical parameter 
for the success of full electric (FEA) or hybrid electric aircraft (HEA). The Bauhaus Luftfahrt e.V. focuses on a broad spectrum of alternatives to conventional propulsion technologies and sources of energy for aircraft. In their investigation of regional [4] and short to long distance aircraft such as the CeLiner [5-7] propulsion technologies suitable for FEA and HEA concepts are discussed and electric air transport appears to offer a promising perspective [6]. Encouraged by a retrofit of an A320, block fuel can be significantly reduced (by $16 \%$ ) considering a hybrid propulsion concept including a battery [8] Although these researchers differentiate between the power and the energy delivered by the electrical system, a propulsion operation strategy is missing. Deeper insights about the role of the embedded battery performance in the overall aircraft design (OAD) are not provided. Isikveren et al. [9] make first research efforts about hybrid electric propulsion strategies. Nevertheless, only the cruise mission segment is regarded and battery specific parameters such as power-to-energy ratios are not considered. Additionally, a comprehensive overview of implications on operating costs by introducing these new propulsion systems is not found. In [10], studies about the costs mainly focus on the battery technology only.

A large spectrum of new propulsion concepts is developed by NASA in cooperation with Boeing. In the LEAPtech project, distributed propulsion, its aerodynamic effects [11] and larger aircraft with aft fuselage propulsors [12] are investigated. In their PEGASUS concept $[13,14]$ a wingtip propeller architecture is applied for a regional aircraft, highlighting the propulsion system and different fixed battery energy settings. The PEGASUS concept shows that battery hybrid to conventional propulsion vehicles offer a limited economic competitiveness for low battery specific energy $(<600 \mathrm{Wh} / \mathrm{kg})$ and high electricity costs. However, only the battery energy performance is considered and not the correlating power. There is a lack of investigation regarding different battery technologies with high energy and/or power requirements.

Researchers of the Deutsches Luft- und Raumfahrt Zentrum (DLR) are part of the Clean Sky II project, in which new propulsion architectures for regional and bigger aircraft are analyzed. First considerations about aerodynamic improvements are made. Parallel hybrid concepts with two gas turbines and electric driven wingtip propellers are most suitable for improvements with regard to fuel savings among the screened concepts [15]. The propulsion system is designed to recharge the battery in flight. Thus, the battery is only used for power peak shaving. Alternative operation strategies are not considered.

The TU Delft [16] modified a regional aircraft with a hybrid battery electric propulsion system. Fuel weight reductions up to $30 \%$ are expected for hybrid electric aircrafts concepts. Nonetheless, a battery specific energy of at least $750 \mathrm{Wh} / \mathrm{kg}$ is required. The author does not go further to investigate the role of the power and energy output of a battery and its implications for future battery research.

The VOLTAIR plane from Airbus is a feasibility study about a FEA that defines technological pre-conditions for the energy density of batteries and flight missions [17]. The study underlines the importance of battery development to fulfill the energy requirements for electric flights. A more detailed analysis of HEA concepts and the power density of batteries is missing.

Most of the research does not provide a clear message for politicians and aircraft manufacturers about the profitability and environmental friendliness of HEA. The main identified research gap is the lack of investigation on the role of the two basic battery performance parameters, power and energy density and an operation strategy depending on a clear goal setting. The Flightpath 2050 targets a significant $\mathrm{CO}_{2}$ pollution reduction. The emission measurement is twofold. Airlines and aircraft manufacturers care about the emissions during flight, meaning tank-to-wheel- emissions. If the environmental impact of aviation is seen more holistic, the well-to-tank-emissions have to be added in the environmental analysis. Both perspectives are considered in the following. Research about technological specifications and market trends is very rare for 2050. Hence, the year 2035 is taken as research scope. In the airline industry cost reduction is a main focus for managements to stay competitive. Hence, in this research HEA configurations are tested regarding their $\mathrm{CO}_{2}$ emission savings and operational cost competiveness. Therefore, HEA with battery and gas turbine propulsion architectures are in scope. 
Within this contribution battery operation strategies in an HEA aircraft are discussed on the example of a regional aircraft. This is due to three reasons. First, a large market growth is predicted for regional aircraft with more than 60 PAX-6000 new deliveries until 2033 [18]. Second, this segment has a significant environmental impact with $14 \%$ of total aviation $\mathrm{CO}_{2}$ emission [19]. Third, the length of typical flight profiles is limited compared to short-to-medium-haul flights. The longer the flight the more important is the energy density of the energy storage device to fulfill the mission requirements [20]. The combination of power and energy requirements for shorter, regional flights promises to provide more insights in the battery design. The fuel efficient regional aircraft, ATR 72 [21], with 70 PAX is chosen as a reference aircraft. A sophisticated OAD model is developed to investigate the influence of HEA on the design parameters.

A promising aircraft architecture is selected and an overview of the state-of-the-art technology is given first. Then, a propulsion operation strategy and the aircraft design model for HEA are defined. The simulation results for different batteries are analyzed and the impact of the battery sizing on the OAD is described. Finally, the environmental impact is clarified in form of sensitivity studies on the $\mathrm{CO}_{2}$ emissions.

\section{Propulsion Technology}

In this section, an overview of the state-of-the-art in hybrid technologies and aircraft propulsion is given. The propulsion operation strategy which is needed for the simulation of an OAD is defined. Figures of merit are introduced to analyze the effects of introducing hybrid electric propulsion in aircraft.

\subsection{Propulsion Architecture}

The hybridization of the propulsion system enables new propulsion architectures that lever additional aerodynamic improvements. An extreme example is the distributed propulsion concept with more than ten propulsors [22] The new arrangement of propulsors can lead to better aerodynamic lift properties of the wing [12]. A variation of this concept is an architecture with two electric-driven wingtip propellers and a conventionally placed gas turbine on each wing (Figure 1). This wingtip propeller architecture described by DLR [15] and NASA [13] promises better lift properties of the aircraft and limited weight as well as cost increases. A larger number of engines can lead to lower oversizing factors of the power rating for each propulsor which is sized due to the one engine inoperative (OEI) case.

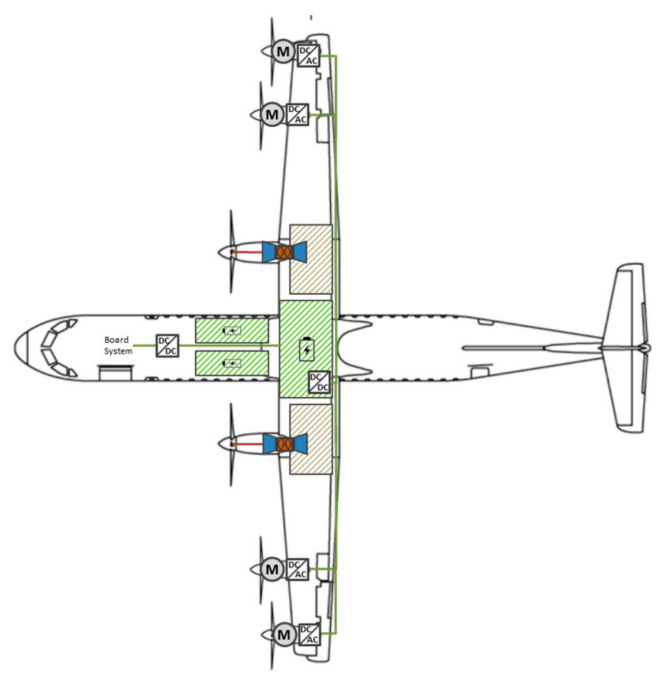

Figure 1. Schematic wingtip propeller architecture for an ATR-72. 
The vertical tail is also designed for steering momentums in the OEI case. When the engines are controlled and differential thrust is used, smaller momentums have to be handled by the V-Tail and a smaller sizing is likely [22]. These advantages are expected by introducing new propulsion technology. Architectures with numerous gas turbines cause higher costs due to increased maintenance costs. It is assumed that electric propulsion leads to decreased maintenance efforts [23], so no severe cost penalty has to be applied for an architecture with more than two electric engines.

\subsection{Scope of Propulsion Components}

In this section, the propulsion components used in the simulation of a HEA and their characteristic values are introduced. The gravimetric density, component weight respectively, is the most important parameter for choosing propulsion components [24,25]. Additional mass, which has to be carried in flight, costs more energy for the transportation, because an increased maximum takeoff weight (MTOW) requires a higher demand of thrust to move the aircraft.

\subsubsection{Conventional Propulsion Components}

Conventional larger aircraft are powered by jet fuel. They are characterized by a very high energy density with a lower heating value of $11.9 \mathrm{kWh} / \mathrm{kg}$ [5]. The fuel mass is reduced with the mission time as the kerosene is burnt. The chemical energy is converted into mechanical energy. This process has a relatively low efficiency of about $40 \%$ [14], which even decreases for lower power ratings of the turbine [26]. A ducted or unducted fan is mounted on the main shaft of the gas turbine to provide thrust. The choice of the thrust technology depends on the cruise speed [27]. Unducted propellers have a higher efficiency than ducted fans for slower speeds. The chosen cruise speed for the regional reference aircraft is slower with Mach 0.44 compared to cruise speeds of short-haul jets with Mach $>0.76$. Hence, unducted propellers are chosen for the reference aircraft.

\subsubsection{Electric Propulsion Components}

The electric motor is a propulsion technology that draws electricity for operation. A power management and distribution (PMAD) system in form of inverters, converters and cables is needed to ensure safe operation of the motor controlling the voltage and current levels [28]. State-of-the-art electric motors are not often designed for applications with weight limitations and have gravimetric power densities between 2-10 kW/ kg [5]. The weight of the PMAD is added. Latest research focuses on high temperature superconducting (HTS) materials that offer the best available power to weight ratios [29] with power densities up to $40 \mathrm{~kW} / \mathrm{kg}$ [30]. These superconducting materials conduct currents with nearly no resistive losses [31]. HTS materials have to be cryocooled under a critical temperature of $27-77 \mathrm{~K}$ to enable superconducting [32]. Reports from NASA [33], the BHL [34] and Masson et al. [35] predict gravimetric power densities between $7-25 \mathrm{~kW} / \mathrm{kg}$ for HTS motors including cryogenic cooling with efficiencies from $95-99.5 \%$. The efficiency of electric motors is not highly dependent on the rated power output in comparison to gas turbines [14]. As a design requirement for the PMAD components the rated voltage of the electric propulsion system is needed. Vratny et al. [28] and Jones et al. [36] prove that a system voltage of $3 \mathrm{kV}$ (DC) leads to the highest efficiency for all electric demands, which is chosen for the simulation. Voltage variations are handled by the converters and inverters. Values for commercially available power electronics in the year 2035 go up to $26 \mathrm{~kW} / \mathrm{kg}$ [37]. Efficiencies are around $98-99.5 \%$.

However, the weight of cryocoolers has to be taken into account in addition to the motor and PMAD power to weight ratios. Since the systems come with a high fixed weight for pumps and tanks, these are assumed to offer weight reduction potential for larger aircraft only. Consequently, conventional electric components are chosen for the regional aircraft, but it is assumed that the product improvement until 2035 leads to similar power to weight ratios compared to HTS components. Nevertheless, the component efficiencies are significantly lower. 
The power density of cables does not directly depend on the power rating, but on the maximum current that is conducted and the cable length. A nickel-plated aluminum cable already tested in an aircraft context is chosen with $0.00324 \mathrm{~kg}$ per A per $\mathrm{m}$ and an efficiency of $98.5 \%$ [38].

One of the main differences between the conventional system and the battery-based aircraft is that the consumption of jet fuel leads to less weight during flight, whereas the battery mass remains constant. Some technologies as the Lithium-Air (Li-Air) battery even gain weight. The performance of the battery depends on the materials used-especially for the electrode and electrolyte [16]. Electrochemical batteries are energy storage systems that do not allow an independent design of the installed power and energy. Installation of additional system power is always associated with additional energy of the system, which is due the integral structure of the battery. A good measure for battery performance in this regard is the power-to-energy ratio (P/E-ratio), which relates the batteries peak power to the according energy capacity. Inherently, a design tradeoff between a high power, high energy performance respectively, is given. Therefore, it is important to choose a battery technology, with its specific ratio of power and energy, in accordance with the requirements of the application. Current technologies as the Lithium-Ion (Li-Ion) batteries, which are used for electric vehicles, reach gravimetric energy densities of only $0.3 \mathrm{kWh} / \mathrm{kg}$ [5]. Technologies such as Lithium-Sulfur (Li-S) and Metal-Air batteries are in a practical prototype and early stage demonstrator phase, respectively [24]. Gravimetric energy densities of Li-S can theoretically reach $2.6 \mathrm{kWh} / \mathrm{kg}$ (Yang et al., 2010), but commercially produced batteries are expected to be realized with $0.65 \mathrm{kWh} / \mathrm{kg}[39,40]$. The power density varies significantly from 0.4 [16] to $1 \mathrm{~kW} / \mathrm{kg}$ [41]. The suggested potential of Li-Air storages varies significantly. Assumptions of gravimetric energy densities are around $1 \mathrm{kWh} / \mathrm{kg}$ [17]. The business case of batteries also depends on the lifetime cycles of the battery system. First tests proved that the Li-S systems are able to last for 1500 cycles in this stadium of development [42].

\subsection{Sizing and Operation Strategy}

A propulsion operation strategy is defined to determine the optimal power and energy rating of the conventional and electrical propulsion components according to the overall goal setting and the operation of these in each mission phase.

\subsubsection{Degree of Hybridization (DoH)}

The degree of hybridization $H_{P}$ describes the power ratings of the electric motor $P_{E M, \text { max }}$ and the gas turbine $P_{G T, \max }$ depending on the required total system power $P_{\text {Total,max }}$ :

$$
\begin{gathered}
H_{P}=\frac{P_{E M, \max }}{P_{T o t a l, \max }}=\frac{P_{E M, \max }}{P_{E M, \max }+P_{G T, \max }} \\
\text { with } P_{G T, \max }=\left(1-H_{P}\right) P_{\text {Total,max }} .
\end{gathered}
$$

In the conventional case, $H_{P}=0$, only two gas turbines are used. A FEA, $H_{P}=1$, has four wingtip propellers. The choice of propulsion architecture depends on a basic decision, if the operation of the aircraft can depend on ground charging infrastructure at airports or not. Otherwise, the battery has to be recharged in flight by the gas turbine and a generator, which requires additional fuel. As the weight of the propulsion system is the critical limitation of the technological feasibility of hybrid electric aircraft, a strategy including on-ground charging is chosen. On board re-charging causes higher weights for the additional components and fuel. Consequently, the gas turbine and electric motors are not connected (Figure 1) and the power rating of the battery is calculated with the efficiency of the electric system $\eta_{\text {Elec }}$ :

$$
P_{B a t, \max }=\frac{P_{E M, \max }}{\eta_{E l e c}}
$$




\subsubsection{Battery Energy Strategy}

The operation strategy of the battery can be manifold. A simplified mission profile for the total system power is shown in Figure 2. Each flight phase, e.g., takeoff, climb, cruise, is shown with a constant power setting. Two extreme strategy options are likely.

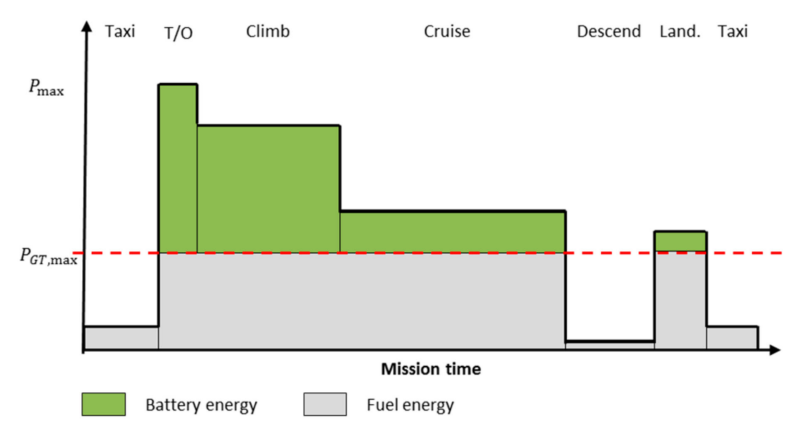

(a)

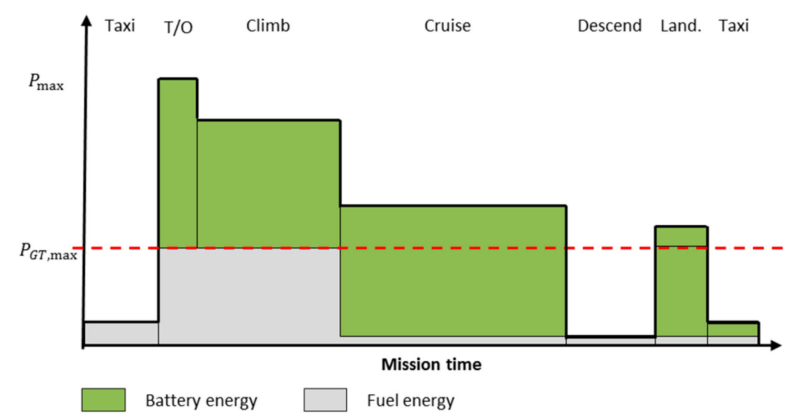

(b)

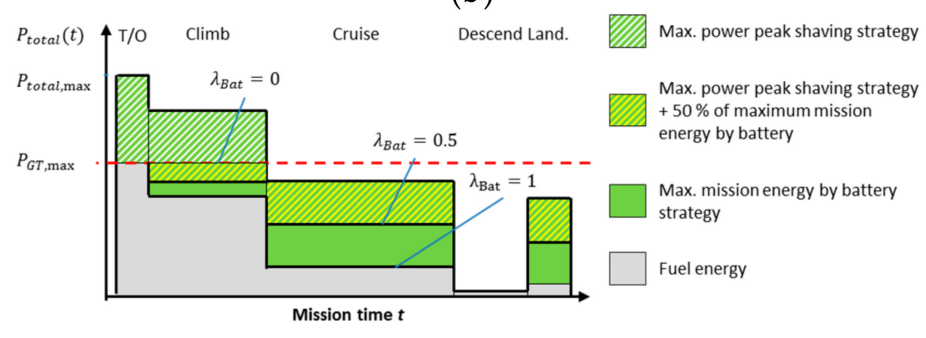

(c)

Figure 2. Definition of battery operation: (a) maximum power peak shaving strategy; (b) providing maximum battery energy depending on electric motor power sizing; (c) battery strategy parameter definition.

The first option is a minimum battery sizing to provide energy for maximum power peak shaving of the gas turbine power rating (Figure $2 \mathrm{a}$ ). In this case, $H_{P}$ determines the peak shaving limit (red line). The battery is not used for any energy demand below this power rating. The gas turbine can be downsized with this strategy, coherent with the according decrease in weight.

The second strategy is to maximize the battery utilization, since the electric motors and the battery power capability are designed for the maximum power rating. Hence, the battery supplies maximum mission energy in every mission segment depending on its maximum power rating and the maximum required power (Figure 2b). Less fuel is consumed deploying this strategy. Nevertheless, the energy density of the battery is significantly lower than of the fuel. Thus, it seems to be obvious that the first option should be favored to reduce the aircraft weight and its energy demand. However, the hypothesis is established that there is an optimum operation strategy in between these extreme options. Reason for this is that the battery sizing depends on the power and energy requirement. It is derived from the $\mathrm{DoH}$ - the maximum total power demand — and the battery operation strategy. It is assumed that batteries with low power densities could be oversized regarding the energy capacity 
requirements. In this case, it would make sense to utilize the battery as much as possible without larger sizing. Consequently, a variable strategy is introduced for every DoH to test different battery operation strategies between the two extreme points. The battery usage is described with the battery strategy parameter $\lambda_{B a t}$ ranging from 0 to 1 . Maximum power peak shaving strategy (Figure 2a) is reached with $\lambda_{B a t}=0$ and the maximum battery energy strategy (Figure $2 b$ ) belongs to $\lambda_{B a t}=1$. Values of this parameter in between these options are varied and exemplarily shown in Figure 2c. An operation strategy equation that provides the electric power depending on the strategy parameter is defined to determine the battery energy for the mission with Equation (4). It can be translated into the battery power using Equation (3).

$$
P_{E M}(t)=\max \left(P_{\text {Total }}(t)-P_{G T, \max }, 0\right)+\lambda_{\text {Bat }} \times\left(\min \left(P_{E M, \max }, P_{\text {Total }}(t)\right)-\max \left(P_{\text {Total }}(t)-P_{G T, \max }, 0\right)\right)
$$

\subsubsection{Reserve Mission}

In addition to the design flight, a reserve mission for special flight events such as flying to an alternate airport has to be considered for the OAD [8]. The additional energy needed for the reserve mission is carried on-board for each flight, but is mostly not retrieved. Since the battery exploitation is already optimized with the described operation strategy, a minimized usage of the battery is strived for the reserve mission. This equals a $\lambda_{B a t}=0$. The battery is only sized to power the reserve mission, when the gas turbine power rating is not sufficient.

\subsection{Figures of Merit}

As stated in the research question, the central focus of propulsion innovations lies on the reduction of emissions. Different perspectives on $\mathrm{CO}_{2}$ emissions are possible. Airlines and aircraft manufacturers count the tank-to- wheel energy conversion only. In this calculation, electricity is assumed to be generated from renewable energy plants that do not cause emissions. Hence, the emissions are directly proportional to the fuel burn of the aircraft, which causes $3.14 \mathrm{~kg} \mathrm{CO}_{2}$ per $\mathrm{kg}$ fuel [43]. The analysis in Section 4 refers to this perspective only. A holistic investigation of the $\mathrm{CO}_{2}$ emissions of aviation in Section 5 considers additional environmental impacts for the well-to-tank process. Whereas $0.61 \mathrm{~kg}$ $\mathrm{CO}_{2} / \mathrm{kg}$ fuel [43] has to be added for the conventional route, the electricity generation is characterized by an average OECD (Organisation for Economic Co-operation and Development) measure of $0.42 \mathrm{~kg}$ $\mathrm{CO}_{2} / \mathrm{kWh}$ electricity [44]. Second aspect of the overall target is to provide a cost competitive HEA configuration. The direct operational costs (DOC) are measured with a DOC model adopted from Bardenhagen and Goblin [45]. It is adjusted for hybrid electric aircraft. Energy costs for electricity and fuel, depreciation costs of the aircraft including the battery investment, maintenance costs for airframe, propulsion and overhead technology costs, labor costs for crew, airport and navigation fees are considered. A detailed description of the model is provided in Appendix A.

\section{Simulation Methods}

The simulation methods including aircraft top-level requirements, propulsion parameters and the simulation structure are described in this section.

\subsection{Aircraft Top-Level Requirements}

Design requirements are basic input factors needed for the OAD simulation. Main input is the given design mission, for which the aircraft performance is determined. Here, the aircraft top-level requirements include a regional flight with full payload. According to the design of the reference aircraft $95 \mathrm{~kg}$ per PAX are chosen [46]. A NASA study of regional ( $<900 \mathrm{NM})$ air transportation demand in the US in 2030 depicts that $85 \%$ of all trips will be less than 350 NM long [13]. Hence, a design range of $350 \mathrm{NM}$ is chosen for this simulation, which equals $648 \mathrm{~km}$. Design missions for this type of aircraft are in an altitude of FL250 with Mach 0.44. Takeoff field length is $1200 \mathrm{~m}$ and landing length is $1060 \mathrm{~m}$. Safety requirements for reserve mission and the OEI case are incorporated in the simulation 
with a $45 \mathrm{~min}$ of additional cruise in $1500 \mathrm{ft}$ as reserve and a minimum gradient of second climb with $2.4 \%$ for twin-engine aircraft and $3 \%$ for aircraft with four or more engines [47].

\subsection{Propulsion Parameters}

The parameters used in the simulation are summarized in Table 1. Gravimetric densities and efficiency factors of the chosen technologies include subsystems such as cooling. HTS technology, which has the main advantage of causing fewer losses, is not applied. Hence, lower efficiencies of the electric motor and PMAD comparable to current technology are chosen. The power densities for these conventional cooled systems are assumed to develop similar to HTS components. The previously described nickel-plated aluminum cable is taken. The current rating is derived from the maximum power that each of the electric motors delivers. The length of the cables is equal to the distances between the energy source and the electric motors.

Table 1. Overview of electric propulsion components parameters.

\begin{tabular}{|c|c|c|c|}
\hline Components & Gravimetric Densities & Efficiencies & Sources \\
\hline Electric motor & $15 \mathrm{~kW} / \mathrm{kg}$ & $95 \%$ & {$[30,33-35]$} \\
\hline Inverter/converter & $20 \mathrm{~kW} / \mathrm{kg}$ & $98 \%$ & {$[37,48]$} \\
\hline Electric cable & $0.00324 \mathrm{~kg} / \mathrm{A} / \mathrm{m}^{1}$ & $98.5 \%$ & [38] \\
\hline Battery 1 (low power Li-S) & $\begin{array}{c}0.65 \mathrm{kWh} / \mathrm{kg} \\
0.4 \mathrm{~kW} / \mathrm{kg}\end{array}$ & $90 \%$ & {$[16,39,40]$} \\
\hline Battery 2 (high power Li-S) & $\begin{array}{c}0.65 \mathrm{kWh} / \mathrm{kg} \\
1 \mathrm{~kW} / \mathrm{kg}\end{array}$ & $90 \%$ & [39-41] \\
\hline Battery 3 (similar to Li-Air) & $\begin{array}{c}1 \mathrm{kWh} / \mathrm{kg} \\
1 \mathrm{~kW} / \mathrm{kg}\end{array}$ & $90 \%$ & {$[17,49]$} \\
\hline
\end{tabular}

${ }^{1} 3 \mathrm{kV}$ system voltage chosen.

Three different batteries are used in the simulation. There are many challenges in handling metal-air battery systems, e.g., material testing in an oxidation environment [49]. Thus, there is a high uncertainty that these systems will be commercialized until 2035 [50]. Consequently, Li-S cells with a high power performance (Battery 2) are chosen for the main simulations. Improved gravimetric densities are assumed to be reached in the next decades as the battery pack gravimetric density is chosen to be the same as the current cell gravimetric densities found in the literature [40-42]. The gravimetric densities of Battery 3 are adopted from prospective metal-air systems. Effects as gaining weight when a metal-air battery is discharged are not considered. The efficiency of the batteries is kept pessimistic with $90 \%$ as the efficiency decreases with a lower state of charge (SOC). This ensures that the battery delivers the required power at each SOC. In the simulation of the battery performance, a unified energy model is included in the simulation which allows a maximum discharging capacity of $80 \%$ to ensure a longer lifetime of the battery. A battery specific polarization model considering cell voltage and discharge current in dependence on SOC is not required in this early design stage.

\subsection{Simulation Structure}

In addition to the advantages of HEA such as lower in-flight emissions, lower noise, more efficient energy conservation and more-reliable systems, a wide range of other novel technology integrations can be enabled [19]. For example, HEA allows the efficient application of wing tip vortices without having the efficiency and weight penalties of small turbo-machinery. The study of HEA impacts can be regarded as a vehicle trade-off or optimization problem that faces multiple technology scenarios and challenges.

The basic modeling approach is based on the aircraft design and optimization tool which considers the major flight phases such as takeoff, climb, cruise, descend and landing. The modeling approach is 
described in detail in [51]. Therefore, within this contribution only a brief introduction of the main features is provided. It highlights the most relevant methods developed for the current hybrid electric propulsion applications instead of giving a general detailed description of the tool. Figure 3 describes the general approach of the modeling structure, which follows a typical aircraft conceptual/preliminary design logic [52-55]. Some important points are discussed in the following to better illustrate the features and modeling strategies.

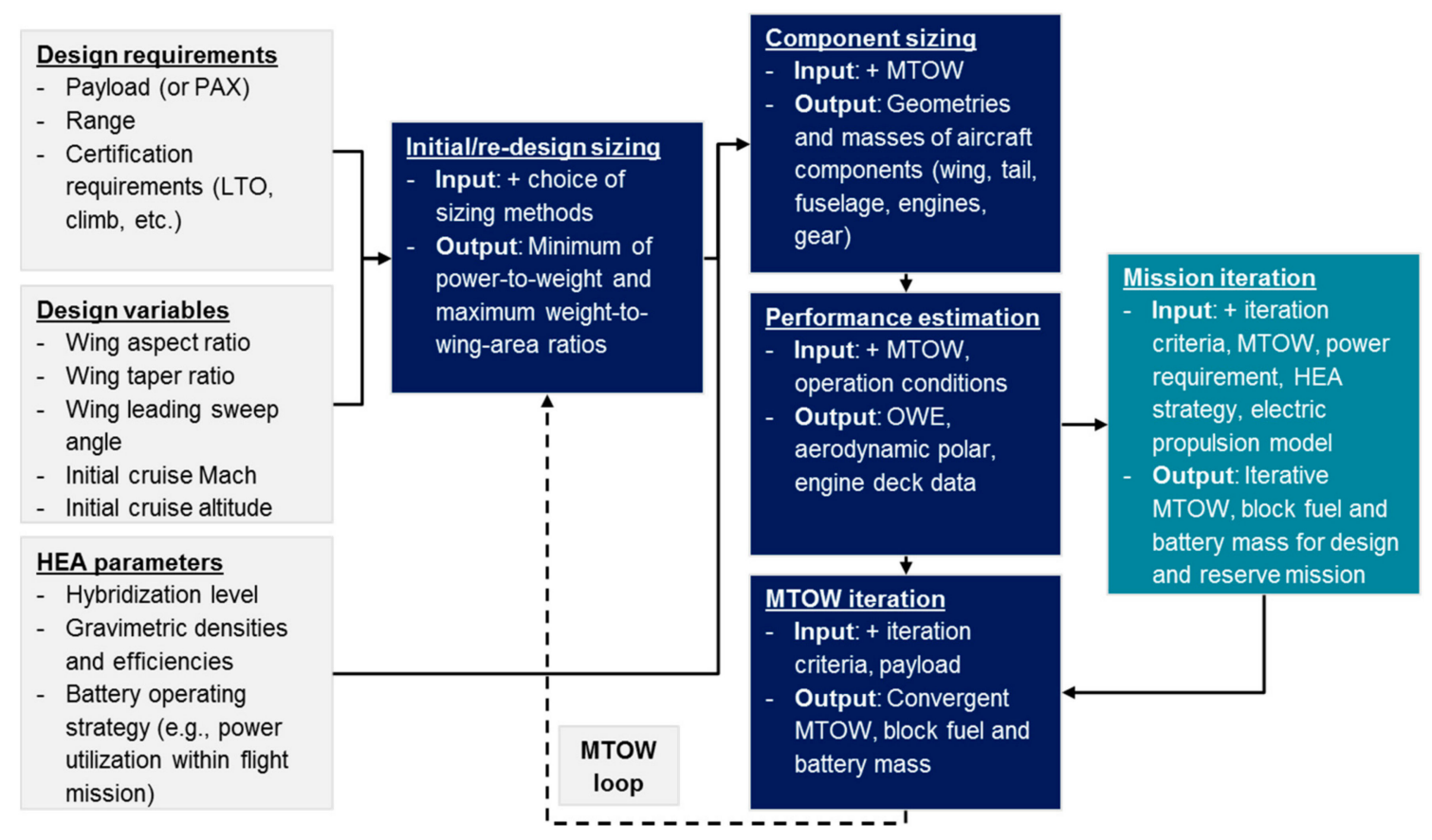

Figure 3. Flow diagram of the general approach for modeling HEA.

Design requirements and constraints such as landing and takeoff (LTO) as well as climb to fulfil certification requirements are included in the HEA modeling for a given design payload and design range. For example, the methods to determine the power-to-weight $(\mathrm{P} / \mathrm{W})$ ratio boundary for second climb gradient constraint at one-engine-inoperative condition are added to reflect the impact of the $\mathrm{DoH}$. This means that the case of four or six engines installed is considered in the power rating sizing of the engines. It can lead to less performance oversizing of each propulsor. Like the multidisciplinary design optimization (MDO) approach for conventional aircraft design, aircraft planform parameters, such as wing aspect ratio, taper ratio and operational parameters such as flight altitude and speed can be selected as design variables or can be considered as design parameters.

Besides the HEA strategy parameters the propulsion parameters are included into the modeling approach. Within mission iterations, the HEA parameters are utilized to deliver corresponding component information and energy requirements. Similar to the engine performance estimation methods for turbofan engines introduced in [51], within this contribution a modified method has been developed for turbo-prop engines. The engine performance calculations are based on published data, such as FAA/EASA engine certification data and ICAO engine emission database. Howe [56] has formulated several empirical methods for engine available thrust at different flight speeds and flight altitudes as well as the specific fuel consumption depending on speed and altitude. Improvements are done to give more reliable prediction of the engine performance data. This is extremely important for new entry into service engines as they usually incorporate new technologies that can significantly enhance the engine performance compared to historical performance data. Reliable data of the gas turbine performance in 2035 are not found in literature. Hence, a state-of-the-art engine performance 
model is chosen. Equations (5) and (6), which are taken from [56], are varied using more detailed and reliable data achieved from GasTurb [57] modeling:

$$
\begin{gathered}
T=k_{1} P_{0} \sigma^{k_{2}} / M_{N} k_{3}, \\
\text { PSFC }=c_{1}\left(1-c_{2} P_{0} \times 10^{-3}\right)\left[1-M_{N} c_{3}\right],
\end{gathered}
$$

where $T$ and PSFC are available operating thrust and power specific fuel consumption at desired given condition, $P_{0}$ is the sea level maximal power, $\sigma$ is the air density ratio (operating flight altitude to sea level), which represents the impact of flight altitudes. $k_{i}$ and $c_{i}$ are to-be-determined factors. It has to be noted that $k_{i}$ and $c_{i}$ can be selected based on thrust output requirement, which depends on flight altitudes and Mach numbers. The values of $c_{i}$ can be selected by detailed engine modeling with a typical combination of $\{2.88,0.025,0.2\}$, as suggested by Howe [56]. In this model, higher drag parameters caused by idling propellers are neglected, which could be achieved by introducing a blade folding mechanism [13].

The described input parameters and models are taken for a first initial aircraft sizing, which delivers minimal power-to-weight and weight-to-wing-ratios (Figure 3). On this basis the components are sized including geometric information such as the vertical tail sizing, which is effected by the different HEA configurations and the wingtip propeller. Performance estimations are iterated over the flight mission. The resulting MTOW converges for each OAD process until an optimal design is found.

A coding for the simulation results is introduced to distinguish between the HEA configurations. RTP-x-y is used to describe the HEA strategy of the regional turbo-prop with the DoH $x$ and the battery strategy parameter y. RTP-0-0 represents a conventional aircraft and RTP-1-1 is a FEA. For the following analysis resolutions of 0.01 for both hybridization and battery strategy parameter are applied.

\subsection{Validation and Verification}

Due to the very limited data of turboprop aircraft available in literature, the ATR-42 aircraft is chosen to verify the validity of the calculation methods. Details about performance and dimensions can be found in [58]. The mass breakdown data of ATR-42 are derived from [59]. As presented in Table 2, the modeling results show very good accuracy for most components.

Table 2. Simulation tool validation: Comparison of the simulated ATR-42 data with reference data.

\begin{tabular}{cccc}
\hline Parameters & Original Data ATR-42 & Calculated Data & Deviation (\%) \\
\hline Passenger number & 48 & 48 & 0 \\
Design range $(\mathrm{NM})$ & 800 & 800 & 0 \\
MTOW $(\mathrm{kg})$ & 16,150 & 16,132 & -0.11 \\
OWE $(\mathrm{kg})$ & 10,253 & 9266 & -9.63 \\
Wing mass $(\mathrm{kg})$ & 1565 & 1558 & -0.45 \\
Fuselage mass $(\mathrm{kg})$ & 2587 & 2394 & -7.46 \\
Vertical tail plane mass $(\mathrm{kg})$ & 322 & 319 & -0.93 \\
\hline
\end{tabular}

\section{Results}

The simulation results of the battery performance and its influence on the OAD are investigated in this section. The results of the HEA configurations with $H_{P}=[0.1,0.9]$ are pictured in heat maps. The $\mathrm{DoH}$ is shown on the $\mathrm{x}$-axis and the battery strategy parameter on the y-axis. A color scale is given for the values of the parameters. A scale limit is introduced for each parameter as these can exceed reasonable magnitudes for some HEA configurations. The OAD parameters correlate with each other and a significant growth of one parameter has a reinforcing effect on others. The limits are set, when the exponential growth of the parameters increases critically. This is decided for each parameter individually. Values beyond these limits are displayed in white. Since the conventional RTP-0-0 and 
the full electric RTP-1-1 are extreme cases of the hybridization strategy, their parameter values are given in the text and are separately displayed within the following discussion.

\subsection{Fixed Battery Simulation}

\subsubsection{Battery Parameters}

The battery mass is displayed in Figure 4a,b. Figure 4a shows the battery mass in dependence of the hybridization parameter varied between 0.1 and 0.9 as well as the battery strategy parameter $\lambda_{\text {Bat }}$. Figure $4 \mathrm{~b}$ aims to show additionally the $\lambda_{\text {Bat }}$-independent battery weight in case of the conventional RTP-0-0 and the full electric aircraft RTP-1-1.

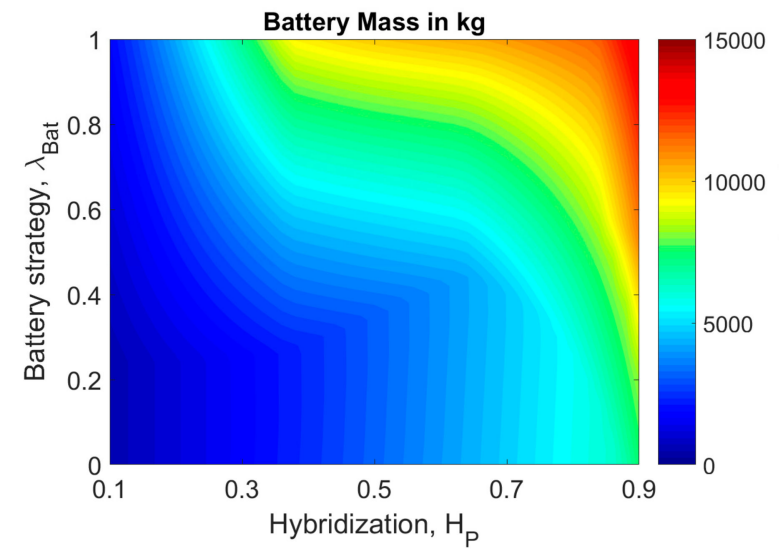

(a)

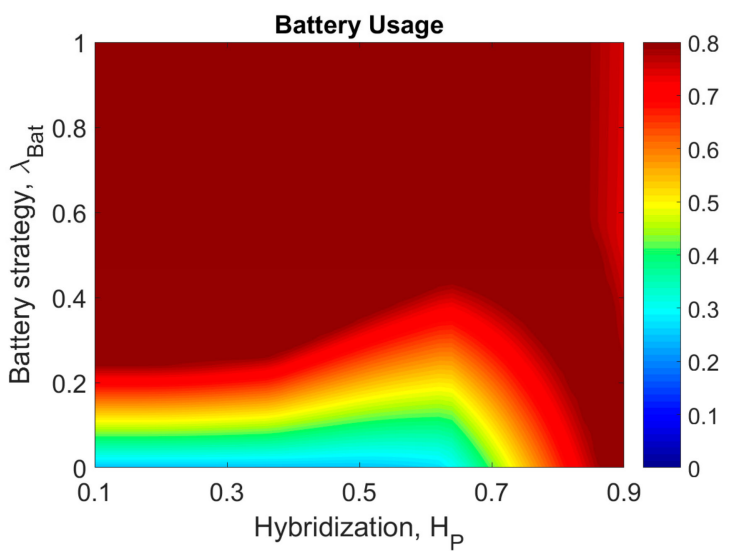

(c)

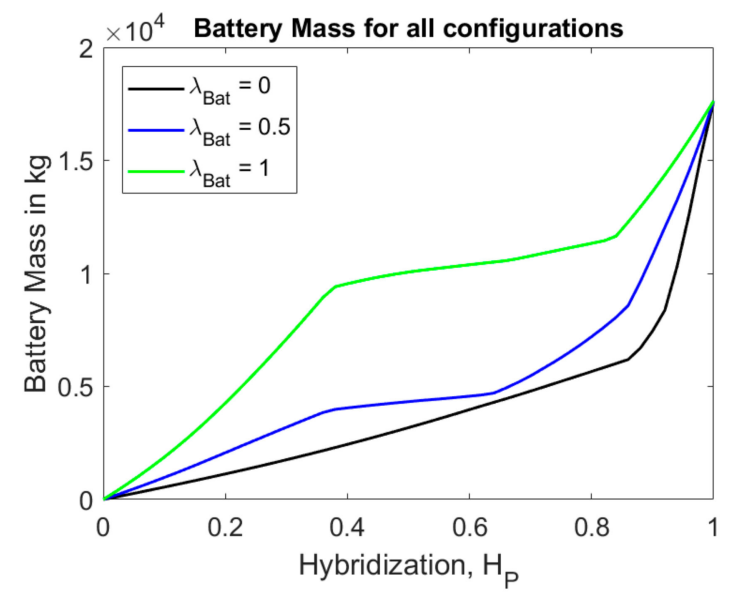

(b)

Figure 4. Battery parameters in case of Battery $2(0.65 \mathrm{kWh} / \mathrm{kg}, 1 \mathrm{~kW} / \mathrm{kg})$ : Battery mass in $\mathrm{kg}$ for (a) Hybrid electric aircrafts $\left(H_{P}: 0.1-0.9\right)$; (b) all degrees of hybridization (exemplary $\left.\lambda_{B a t}\right)$; (c) Battery usage.

The battery weight increases with a higher DoH and exceeds 15 tons for a FEA. An extreme mass growth is observed for HEA configurations with $H_{P}>0.8$ and $\lambda_{B a t}<0.7$. The battery weight for high mission energy supply by the battery $\left(\lambda_{B a t}>0.6\right)$ already reaches 10 tons with $H_{P}=0.4$. There is an optimal battery strategy parameter for a fixed hybridization that leads to a minimum battery weight, e.g., for $H_{P}=0.4$ and $\lambda_{\text {Bat }}=0.3$.

The energy demands for larger $\lambda_{B a t}$ than the optimum increases and leads to higher battery weights. The battery masses for lower strategy parameters than the optimum and the same hybridization are similar. Figure $4 \mathrm{~b}$ underlines the effect that high battery strategy parameters such as $\lambda_{\text {Bat }}=1$ cause extremely high weights for low hybridization levels, whereas moderate and small strategy parameters $\left(\lambda_{B a t}<0.6\right)$ are mostly dominated by the power rating requirement and grow 
slower for $H_{P}<0.9$. Figure $4 \mathrm{c}$ highlights the battery energy usage percentage, which has its maximum of $80 \%$ as the minimum state of charge is limited to $20 \%$ and equals the depth of discharge. This heat map clarifies the exploitation of the battery energy, which is sized according to the power output or the mission energy requirements, depending on which of both is limiting for battery design. It is best exploited for increased $\lambda_{\text {Bat }}$, because more energy is delivered by the battery for the same power rating, which is fixed with the DoH.

The maximum power rating requirement is the dominating battery sizing criterion for strategies close to maximum peak shaving, e.g., $\lambda_{B a t}<0.3$ and $H_{P}=0.4$. In these configurations, the battery energy capacity is oversized compared to the energy requirement given by the strategy parameter. Hence, its capacity is not fully exploited. Three main effects are observable. First, the usage decreases with an increased $H_{P}=[0.1,0.6]$ and a fixed battery strategy parameter, e.g., $\lambda_{B a t}=0.2$. The power rating increases significantly more than the energy demand for these hybridizations. Only the peak power demand phases as takeoff and climb, which endure less than $20 \mathrm{~min}$, are substituted with the electric propulsion system. Consequently, the power and not the energy demand increases significantly. Second, a contrary trend is observed for $H_{P}=[0.6,0.9]$.

The usage of the battery energy increases for fixed strategy parameters. In cruise flight, the power demand is approximately $40 \%$ of $P_{\text {Total, max }}$. Hence, the power rating of the gas turbine does not fulfill the power requirements for the hybridization in cruise. Even for the maximum peak shaving strategy $\left(\lambda_{\text {Bat }}=0\right)$ and $H_{P}>0.5$, the battery is not only used for the takeoff and climb, but also for the cruise part for all battery strategy parameters. Since the cruise flight accounts for the longest part of the flight, a major demand of mission energy is required in this interval. Consequently, the battery usage increases. Third, the battery mass increases and the usage decreases in the FEA case as the reserve mission in form of the alternate cruise flight of $45 \mathrm{~min}$ in $1500 \mathrm{ft}$ has to be covered by the electric propulsion. This energy is not activated in the normal flight profile. As it is not used battery energy the exploitation decreases.

It can be seen that the optimal battery weights for every DoH depend on the full exploitation of the battery. The results highlight that further sizing of mission energy delivered by the battery with a higher $\lambda_{\text {Bat }}$ causes significantly increased weights.

\subsubsection{Impact on $\mathrm{OAD}$}

Main aircraft design parameters such as the MTOW and the wing span are analyzed to understand the impact of the battery integration (Figure $5 \mathrm{a}-\mathrm{c}$ ). The MTOW consists of wing, airframe, payload, propulsion system including the battery and other system masses. The results for the MTOW (Figure 5a,b) and the wingspan (Figure 5c) emphasize a high correlation with the battery mass developments. Previously, described effects are observable in these heat maps. Optimal designs with the lowest weight and the shortest wings are the same for every DoH as for the battery mass. A FEA reaches a maximum weight of more than 40 tons and a wingspan larger than $36 \mathrm{~m}$. The increased propulsion system mass driven by the battery leads to larger wings. These have to produce a larger lift force, when the aircraft is heavier. It is a self-amplifying effect as the larger wing lead to an increased MTOW. Another effect that increases the MTOW for strategies with unexploited batteries is identified. The battery mass for a fixed hybridization as shown previously is nearly constant up to the local minimum, e.g., $H_{P}=0.4$ and $\lambda_{\text {Bat }}=0.3$. Although the battery could supply more energy for battery strategies $\lambda_{\text {Bat }}<0.3$ and is not fully exploited, the required mission energy is drawn from additional fuel mass. Hence, the total mass increases for strategy parameters below the optimum. 


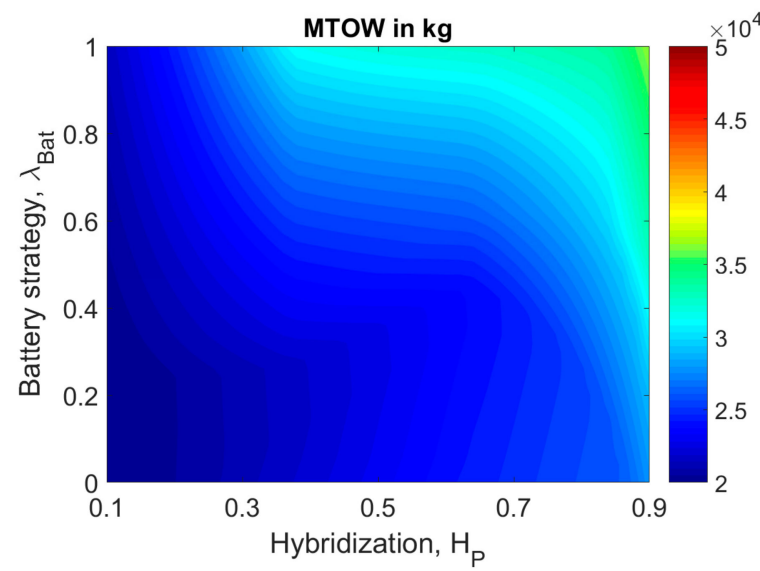

(a)

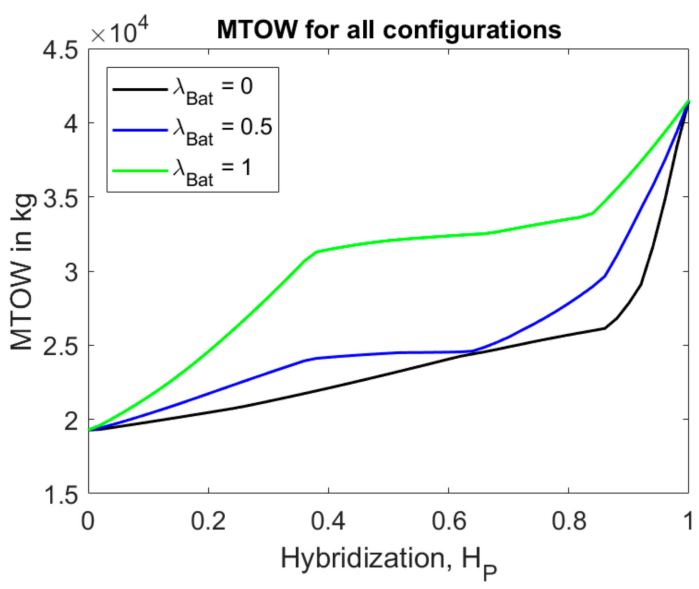

(b)

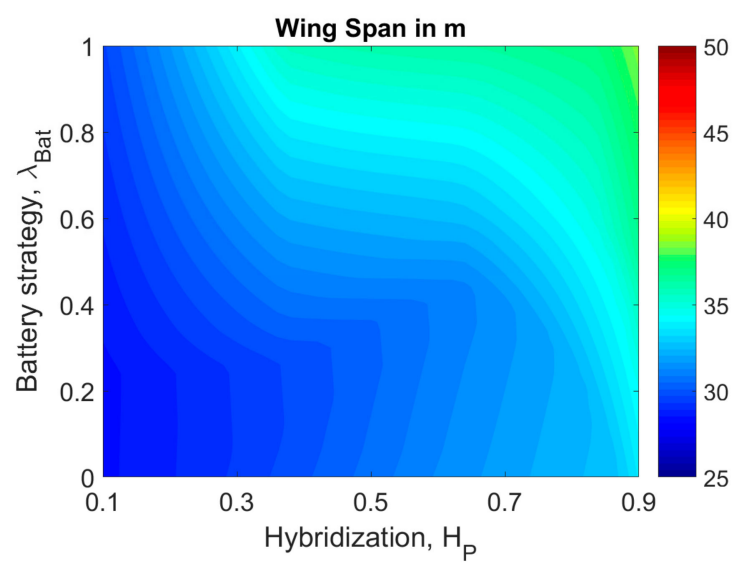

(c)

Figure 5. OAD parameters in case of Battery $2(0.65 \mathrm{kWh} / \mathrm{kg}, 1 \mathrm{~kW} / \mathrm{kg})$ : MTOW in $\mathrm{kg}$ for (a) Hybrid electric aircrafts $\left(H_{P}\right.$ from 0.1 to 0.9$)$; (b) all degrees of hybridization (exemplary $\left.\lambda_{B a t}\right)$; (c) Wing span in $\mathrm{m}$.

\subsubsection{Impact on Figures of Merit}

The battery weight and the MTOW affect the figures of merit. The fuel burn, which is directly proportional to the tank-to-wheel $\mathrm{CO}_{2}$ emissions and the cost competiveness are investigated in Figure 6a. The heat map represents the fuel burn and the contour lines show the DOC per flight. The fuel burn decreases with higher $H_{P}$ and higher strategy parameters, when the battery is sized to substitute maximum fuel energy. In the FEA case, no emissions are polluted during flight. No major fuel burn reductions are achievable for $\lambda_{B a t}<0.4$ and $H_{P}<0.8$, when the battery is not fully exploited and additional fuel has to be carried on board. The DOC per flight contour lines are characterized with a similar pattern comparable with the heat map of the MTOW (Figure 5a). An optimal battery strategy can be determined for every $H_{P}$ of the HEA configurations to minimize the costs (exemplary highlighted as red dots in Figure 6a). Operational costs increase with a higher hybridization. RTP-0.1-0.25 is the only HEA configuration that causes no DOC increase and a fuel burn reduction of $8 \%$.

The FEA causes $48 \%$ higher expenditures per flight (+1854 EUR). Whereas 30\% fuel burn reduction cause a DOC growth of 5\% for RTP-0.45-0.35. RTP-0.75-0.35 leads to emission savings of $48 \%$, but a cost increase of $10 \%$. The results underline that for HEA the most fuel efficient and cost competitive configurations correlate with the exploitation of the battery. Hence, an operation strategy as maximum power peak shaving does not lead to the best result. 


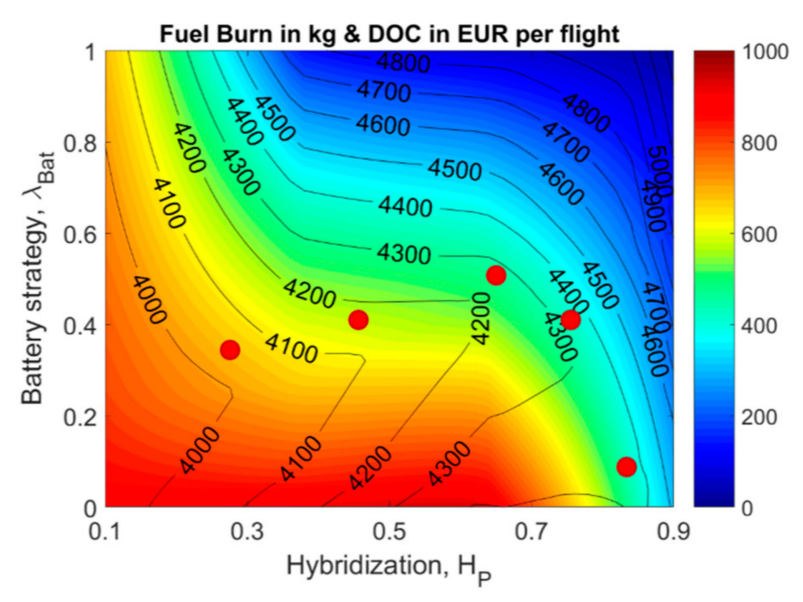

(a)

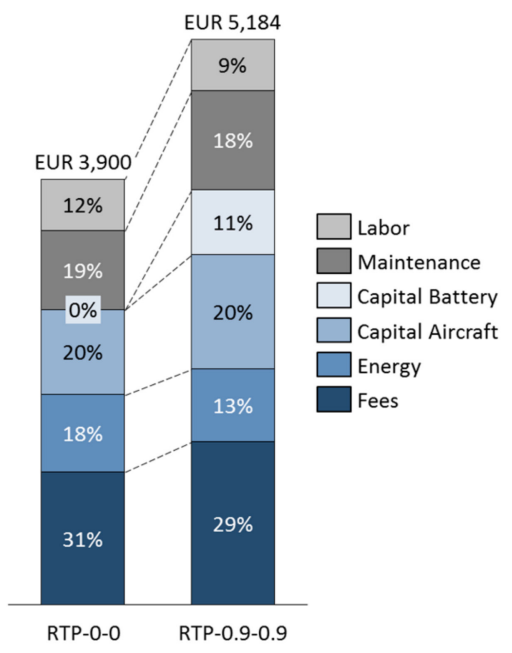

(b)

Figure 6. Figures of merit in case of Battery $2(0.65 \mathrm{kWh} / \mathrm{kg}, 1 \mathrm{~kW} / \mathrm{kg}$ ): (a) Fuel burn in $\mathrm{kg}$ (heat map) and DOC per flight (contour lines); (b) DOC for RTP-0-0 and RTP-0.9-0.9.

A further analysis in Figure $6 \mathrm{~b}$ emphasizes that DOC of HEA configurations are dominated by costs depending on the MTOW and high battery capital costs. Compared to the conventional aircraft, RTP-0-0, the battery and aircraft investment, maintenance costs and fees increase for a HEA, because these correlate with the MTOW and battery mass. Energy costs are reduced due to the higher propulsion efficiency of electric systems and lower costs for electricity. More information about the dependencies of each cost factor is provided in Appendix A.

\subsection{Different Batteries}

The previous analysis clarifies the importance of defining an optimal battery operation strategy. In this section, batteries with varying P/E-ratios as well as power and energy densities are tested. Generally, a required P/E-ratio can be determined for every mission profile of HEA or FEA configurations. Within this contribution a simplified mission profile is used, which includes $5 \mathrm{~min}$ takeoff with a maximum total power of $4 \mathrm{MW}, 70 \%$ power for $15 \mathrm{~min}$ climb, $40 \%$ total power for $55 \mathrm{~min}$ cruise, 10 min descent in idle mode and $5 \mathrm{~min} 30 \%$ power for landing.

This equals 2.6 MWh of mission energy and a mission P/E-ratio of $1.54 \mathrm{~kW} / \mathrm{kWh}$. Operation strategies as power peak shaving of takeoff and/or climb shown in Table 3 require higher P/E-ratios.

Table 3. P/E-ratio specifications of different operation strategies.

\begin{tabular}{|c|c|c|c|}
\hline Operation Strategy & $\begin{array}{l}\text { Maximum Electric } \\
\text { Power Requirement }\end{array}$ & $\begin{array}{c}\text { Total Energy } \\
\text { Requirement }{ }^{1}\end{array}$ & P/E-Ratio \\
\hline Full mission energy & $4 \mathrm{MW}$ & $2.6 \mathrm{MWh}$ & $1.54 \mathrm{~kW} / \mathrm{kWh}$ \\
\hline Takeoff power peak shaving & $0.3 \times 4 \mathrm{MW}=1.2 \mathrm{MW}$ & $0.1 \mathrm{MWh}$ & $12 \mathrm{~kW} / \mathrm{kWh}$ \\
\hline Takeoff and climb power peak shaving & $0.6 \times 4 \mathrm{MW}=2.4 \mathrm{MW}$ & $0.5 \mathrm{MWh}$ & $4.8 \mathrm{~kW} / \mathrm{kWh}$ \\
\hline
\end{tabular}

The electrochemical energy storages listed in Table 1 are compared in Figure 7 to test the influence of the different power and energy requirements. Battery 1 has a low P/E-ratio of $0.62 \mathrm{~kW} / \mathrm{kWh}$ and a power density of $0.4 \mathrm{~kW} / \mathrm{kg}$. This leads to high unexploited battery energy in the FEA and power peak shaving configurations (Figure 7a). Thus, the low power performance causes very high battery weights. These reach technologically feasibility limits for $H_{P}>0.4$ (Figure $7 \mathrm{~b}$ ). Nevertheless, the battery usage is shown for the simulation results that exceed reasonable limits to clarify the battery exploitation 
for the specific P/E-ratio. In this comparison, Battery 2 has an optimal fit to the mission P/E-ratio with $1.54 \mathrm{~kW} / \mathrm{kWh}$ (Figure $7 \mathrm{c}, \mathrm{d}$ ). It offers the best battery exploitation for delivering as much mission energy as possible (RTP-0.9-y or FEA configuration). However, in the FEA case the battery weight increases significantly (Figure 7d), because Battery 2 lacks in total battery energy density and causes a high MTOW and costs. Battery 3 has a P/E-ratio of $1 \mathrm{~kW} / \mathrm{kWh}$. Compared to battery 2 this battery is less utilized for small values of $\lambda_{\text {Bat }}$ (Figure 7e). However, it is characterized by a high energy density of $1 \mathrm{kWh} / \mathrm{kg}$, which causes a limited growth of the battery mass for larger hybridizations-a FEA becomes feasible with a relatively low battery weight of 6 tons (Figure 7f). These results underline that the P/E-ratio of electrochemical storages fit to the flight mission of a regional FEA.

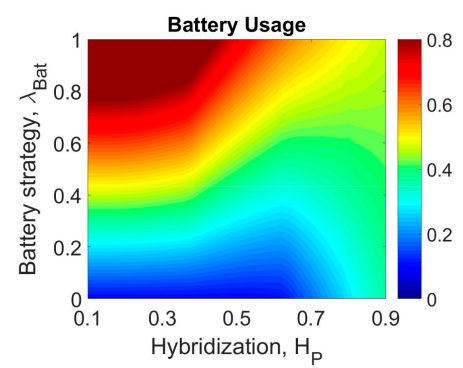

(a)

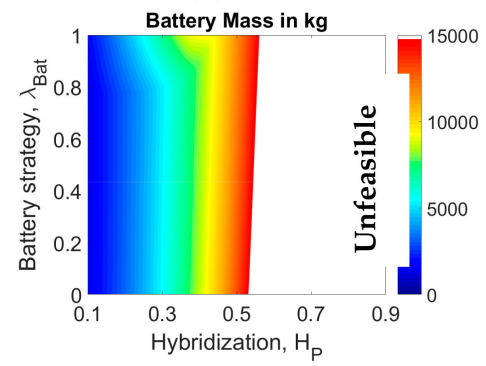

(b)

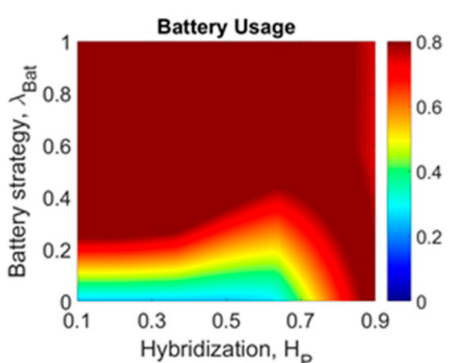

(c)

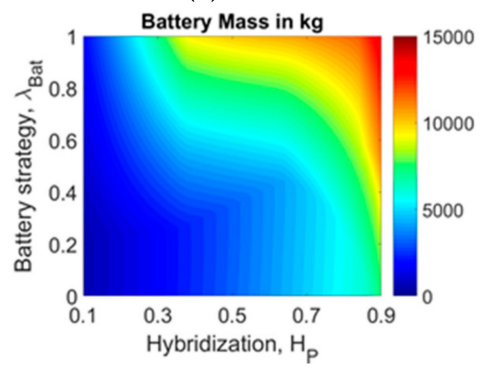

(d)

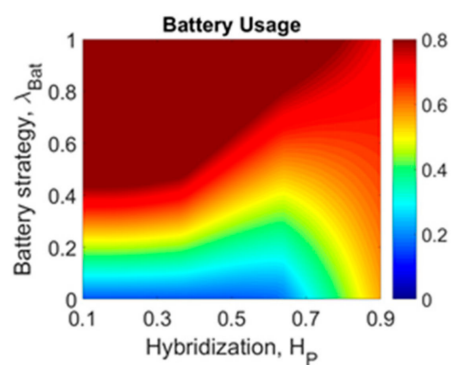

(e)

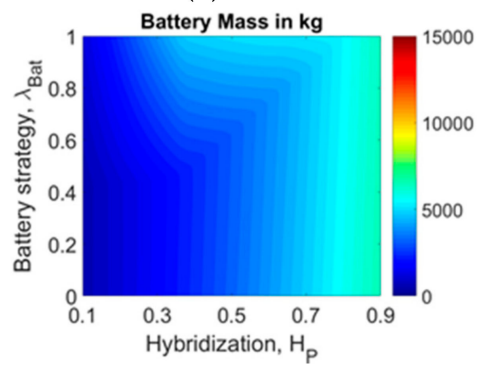

(f)

Figure 7. Battery usage and battery masses: $(\mathbf{a}, \mathbf{b})$ Battery 1 , densities of $0.65 \mathrm{kWh} / \mathrm{kg}$ and $0.4 \mathrm{~kW} / \mathrm{kg}$; (c,d) Battery 2, densities of $0.65 \mathrm{kWh} / \mathrm{kg}$ and $1 \mathrm{~kW} / \mathrm{kg}$; (e,f) Battery 3, densities of $1 \mathrm{kWh} / \mathrm{kg}$ and $1 \mathrm{~kW} / \mathrm{kg}$.

Nevertheless, the power and energy density of the battery limits the feasibility of these OAD. HEA configurations, which are designed for power peak shaving only, require energy storages with higher P/E-ratios. These may not be realizable with electrochemical storages. Mechanical or electrical storages, e.g., flywheels and supercapacitors, respectively, are characterized by larger P/E-ratios $>50 \mathrm{~kW} / \mathrm{kWh}[60,61]$. However, their gravimetric energy densities are low with a maximum of $0.1 \mathrm{kWh} / \mathrm{kg}$. High weights are the result limiting their application in an aviation context.

Generally, the P/E-ratio is an important measure in battery research and has to fit to the flight mission of the targeted aircraft segment. The available battery technology determines the operation strategy, which should focus a full exploitation of the battery energy. The gravimetric densities are the critical battery parameters. These have to be optimized to guarantee technologically feasible HEA configurations in 2035 and beyond. Nevertheless, sensitivity studies of other parameters as the lifetime and the residual value emphasize that these are important levers to make HEA configurations a profitable business case.

\section{Environmental Impact and Sensitivity Studies}

In this section, the environmental impact of HEA and FEA configurations is investigated. The main motivation of reducing emissions of aircraft from a political perspective should be holistic and also consider well-to-wheel emissions. A flight causes the emissions for fuel production and electricity 
generation besides the tank-to-wheel combustion. For considerations of the electricity generation the average OECD mix with $0.42 \mathrm{~kg} \mathrm{CO}$ per $\mathrm{kWh}$ electricity is taken [44]. Propulsion component and aircraft productions are not incorporated in this investigation.

The results are presented in a heat map shown in Figure 8a. Contour lines display the DOC per flight. $\mathrm{CO}_{2}$ emissions decrease with larger hybridization and reach an optimum for RTP-0.66-1 with $22 \%$ savings. A FEA that does not cause $\mathrm{CO}_{2}$ emissions is not achievable, when electricity is drawn with the average OECD electricity production mix. Although the FEA does not cause any emissions in flight, the $\mathrm{CO}_{2}$ pollution increases compared to the HEA configurations with $H_{P}=[0.4,0.7]$ and $\lambda_{B a t}=1$. Due to the highly increased battery weight in the FEA case the total energy demand grows tremendously and the additional electricity demand leads to higher emissions.

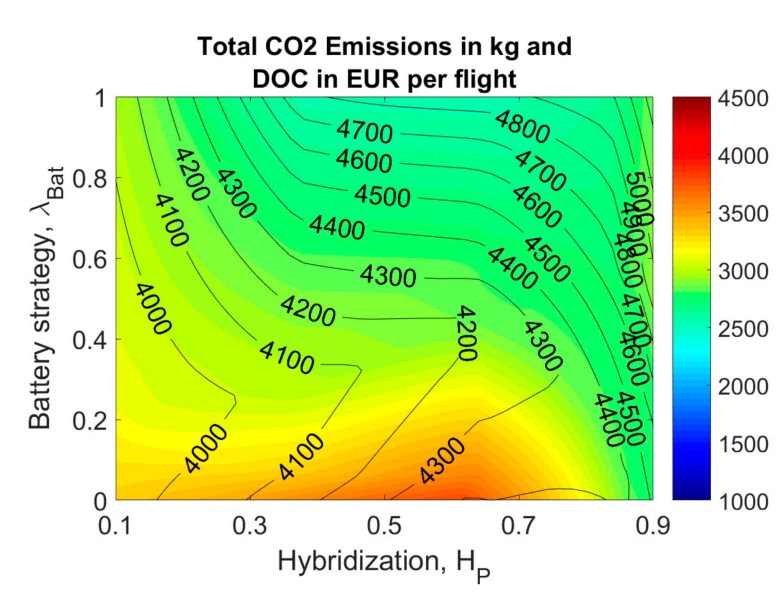

(a)

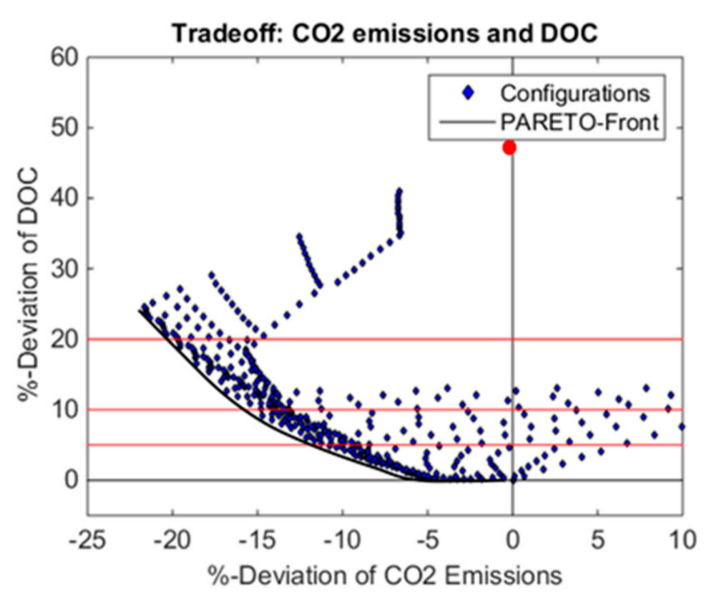

(b)

Figure 8. Total $\mathrm{CO}_{2}$ emissions per flight in case of Battery $2(0.65 \mathrm{kWh} / \mathrm{kg}, 1 \mathrm{~kW} / \mathrm{kg})$ : (a) Total $\mathrm{CO}_{2}$ emissions (heat map) and DOC per flight (contour lines); (b) PARETO-front for optimal configurations.

If the total $\mathrm{CO}_{2}$ emissions and the DOC per flight from Figure 8a are related to the reference aircraft RTP-0-0, the $\mathrm{CO}_{2}$ emissions improvement and deviation of DOC compared to the reference can be obtained. In Figure $8 \mathrm{~b}$ both measures are plotted against each other. Each marker corresponds to one configuration resulting from variation of hybridization and battery strategy parameter in a resolution of 0.05 . This analysis allows to directly identify the change in DOC that correspond to a specific $\mathrm{CO}_{2}$ emission reduction. The so called PARETO-front (black line) represents that configuration, for which the least DOC increase can be obtained for a certain $\mathrm{CO}_{2}$ reduction. It is not possible to further reduce the $\mathrm{CO}_{2}$ emissions without increasing the DOC. It can be directly seen that just minor DOC savings can be achieved for very low $\mathrm{CO}_{2}$ emission reductions. The maximum emission savings of around $22 \%$ are only reached if a $24 \%$-increase of DOC is tolerated. This result can be obtained with a hybridization of 0.66 and a strategy parameter of 1 (RTP-0.66-1). Up to $5 \%$ of emissions can be saved, almost without increasing DOC. In general a clear trend can be observed for higher DOC with higher emission reduction. The diagram also underlines that the FEA (red circle) causes significantly higher costs and does not improve the emission balance. Consequently, the targeted emission savings according to the Flightpath 2050 do not seem realistic, when the pollution aspect is viewed from this macro-economic perspective. The PARETO-front obtained from Figure $8 \mathrm{~b}$ serves as reference for the following sensitivity studies.

These sensitivity studies are made to understand the levers, which influence the environmental impact of electric propulsion in the aviation context. First, the effect of different carbon footprints for the electricity generation is tested. The renewable energy power plant capacity is increasing in most countries. Governments target large shares of these more environmentally friendly power plants for the future electricity generation. The effect of this carbon footprint on the environmental friendliness of HEA is shown in Figure 9a. The PARTEO-front determined in Figure 8 b serves as reference, for which 
a carbon dioxide emission for electricity generation of $0.42 \mathrm{~kg} \mathrm{CO}_{2} / \mathrm{kWh}$ (OECD-mix) is assumed. When the electricity is generated with renewable energy power plants $(0 \mathrm{~kg} / \mathrm{kWh})$, a FEA is free from carbon emissions, but causes $48 \%$ higher DOC. A HEA with $48 \%$ emission savings causes $10 \%$ higher DOC. Countries such as Germany, where the electricity generation relies still significantly on fossil power plants, have higher average carbon dioxide emission per kWh electricity. This is shown with the $+50 \%$ trend $\left(0.63 \mathrm{~kg} \mathrm{CO}_{2} / \mathrm{kWh}\right.$ electricity $)$ in Figure $9 \mathrm{a}$. The trend lines emphasize the large influence of the form of electricity generation on the eco-friendliness of HEA and FEA. It shows that an improved environmental friendliness of aircraft should be combined with further expansion of renewable energy plants.

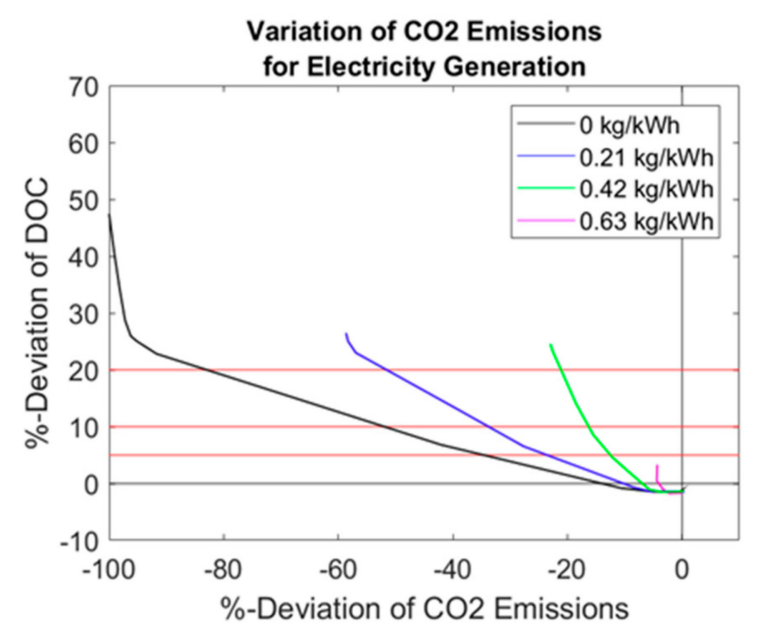

(a)

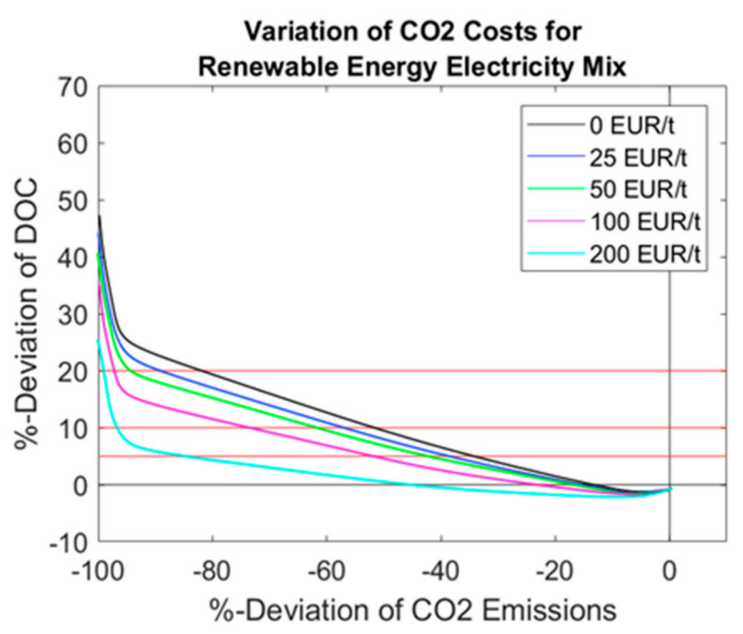

(b)

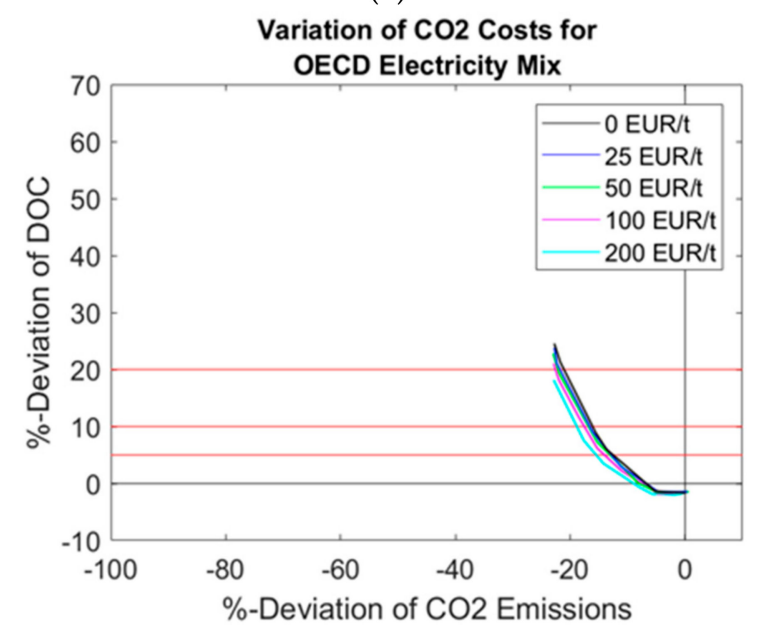

(c)

Figure 9. Sensitivity studies of $\mathrm{CO}_{2}$ factors: PARETO-fronts for (a) variation of emissions of electricity generation; (b) OECD electricity generation mix and variation of $\mathrm{CO}_{2}$ emission costs and (c) electricity from renewable energy only and variation of $\mathrm{CO}_{2}$ emission costs.

If HEA would be available in the next years and draw electricity with the OECD mix, political instruments to reduce pollution could favor the business case of electric propulsion. Mechanisms as carbon dioxide taxes or certificates are discussed by politicians and researchers [62]. Thus, the magnitude of certificate prices that are considered is at least 20-30 EUR per $\mathrm{tCO}_{2}$. In Figure 9b a sensitivity study of such policies for HEA powered with the OECD mix is done. It underlines that these have a very limited impact. No larger cost advantages for HEA or FEA can be found compared to the scenario without $\mathrm{CO}_{2}$ pricing. Almost all PARETO-fronts are equal to the corresponding 
PARETO-front obtained from Figure $8 \mathrm{~b}$ (no $\mathrm{CO}_{2}$ pricing). A benefit of only $5 \%$ less DOC increase is the result of introducing emission certificates with around 200 EUR per $\mathrm{tCO}_{2}$ for RTP-0.66-1 in this OECD emission scenario. The reason for this result can be found in the high carbon dioxide emissions of the OECD electricity mix $(0.42 \mathrm{~kg} \mathrm{CO} / \mathrm{kWh})$, due to which HEA configurations have almost no benefit from $\mathrm{CO}_{2}$ pricing.

Therefore, another sensitivity study in Figure 9c investigates the same lever, but a future scenario, when batteries are charged with emission free electricity. In this case, the emissions directly correlate with the fuel burn of the combustion system. Additional triggers for such external effects could be increased fuel prices due to scarcity of oil resources. This affects the conventional aircraft and HEA configurations with low hybridizations, when larger amounts of fuel are burnt. As the battery energy has no carbon footprint in this scenario, HEA with operation strategies delivering much battery mission energy profit from the penalty costs for conventional systems. These configurations become more profitable compared to the conventional aircraft. If $\mathrm{CO}_{2}$ emissions cost $200 \mathrm{EUR} / \mathrm{tCO} 2$, HEA configurations with $31 \% \mathrm{CO}_{2}$ savings are still cost competitive.

The sensitivity studies depict the two most important political levers for environmental friendly aviation. First, policies that support the expansion of renewable electricity generation and second, costs for burning fuel influence the environmental impact and economic profitability of electric propulsion systems in the aviation context positively.

\section{Conclusions and Discussion}

Within this contribution, the role of the battery in hybrid electric propulsion systems and its impact on the environmental friendliness of such aircraft are investigated. The provided simulation results of HEA configurations in the aviation context clarify that the technological feasibility of HEA mainly depends on the battery performance and thus its weight. An aircraft designer can use the introduced propulsion strategy to optimize future HEA configurations. It has to be distinguished between the power-to-energy-ratio and the gravimetric density performance of the battery. These should be designed to suit the operation strategy and the mission profile of the aircraft. An optimal propulsion strategy has to be found for every OAD to guarantee maximal battery energy exploitation. Thus, battery research efforts should focus on lighter and long-life materials to enable the feasibility of hybrid electric propulsion for aircraft.

The results show that HEA in the regional aircraft segment with 350 NM range can be cost competitive compared to conventional powered aircraft. Furthermore, assuming todays electricity mix, low hybridization (RTP-0.1-0.25) allows moderate (around 8\%) reduction of tank-to-wheel $\mathrm{CO}_{2}$ emissions for similar costs. A RTP-0.66-1 reaches a reduction of emissions by $22 \%$, however DOC increases by around $24 \%$. However, an additional sensitivity study shows that the results have a strong variation with regard to the future development in the electricity sector and possible $\mathrm{CO}_{2}$ pricing.

For example, the macro-economic analysis of the total carbon dioxide emissions of HEA configurations emphasizes the importance of charging the batteries with electricity from renewable sources. The provided sensitivity studies show that policy makers are able to influence environmental friendliness of HEA by pushing the transformation of the electricity generation towards more renewable energy plants. They can also influence the business case of HEA by regulating $\mathrm{CO}_{2}$ emissions in form of higher fossil taxes or a certificate system. Thus, aircraft and electric propulsion component manufacturers can pro-actively shape the future of new propulsion systems for aircraft. This could be achieved by investments into research for faster commercialized, high performance and light electric components. If these requirements are not met in the next decades, it seems unlikely that the targets of the Flightpath 2050 will be met. A further focus on more detailed investigations in several disciplines of the aviation landscape is needed. New aerodynamic concepts, propulsion components and their impact in the overall transportation system are only a few examples of prospective required research.

Acknowledgments: We would like to acknowledge the support of the Ministry for Science and Culture of Lower Saxony (Grant No. VWZN3177) for funding the research project "Energy System Transformation in Aviation" in 
the initiative "Niedersächsisches Vorab". Furthermore, the work was supported by Airbus Operations. We are grateful for the fruitful discussions with Daniel Reckzeh, Lars Joergensen, Peter Rostek, Detlev Konigorski, Kristof Risse and Giorgio Bona. They provided important input in workshops to understand the scope of hybrid electric propulsion in aviation and the relevance of hybrid strategies. The publication of this article was funded by the Open Access Fund of the Leibniz Universität Hannover.

Author Contributions: Julian Hoelzen carried out the analysis and wrote main parts of the manuscript. Yaolong Liu is responsible for the simulation of the hybrid aircraft design in Section 3. Christopher Winnefeld contributed to the battery model and elaboration of the battery strategy. Boris Bensmann analyzed the results as well as conceived and elaborated the objective of the study together with Julian Hoelzen. Ali Elham, Jens Friedrichs and Richard Hanke-Rauschenbach contributed by drafting and critical revisions.

Conflicts of Interest: The authors declare no conflict of interest.

\section{Nomenclature}

$\begin{array}{ll}\text { Abbreviations } & \\ \text { ATM } & \text { Air traffic management } \\ \text { DOC } & \text { Direct operating costs } \\ \text { DoH } & \text { Degree of hybridization } \\ \text { FEA } & \text { Full electric aircraft } \\ \text { HEA } & \text { Hybrid electric aircraft } \\ \text { HTS } & \text { High-temperature superconducting } \\ \text { LTO } & \text { Landing and takeoff } \\ \text { MDO } & \text { Multidisciplinary design optimization } \\ \text { MTOW } & \text { Maximum takeoff weight } \\ \text { OAD } & \text { Overall aircraft design } \\ \text { OEI } & \text { One engine inoperative } \\ \text { OWE } & \text { Operating weight empty } \\ \text { P/E-ratio } & \text { Power-to-energy-ratio } \\ \text { PMAD } & \text { Power management and distribution } \\ \text { PSFC } & \text { Power specific fuel consumption } \\ \text { RTP } & \text { Regional turboprop } \\ \text { SOC } & \text { State of charge } \\ \text { Symbols } & \\ H_{P} & \text { Degree of hybridization } \\ P_{0} & \text { Sea level maximum power } \\ P_{B a t} & \text { Battery power } \\ P_{E M} & \text { Electric motor power } \\ P_{G T} & \text { Gas turbine power } \\ \lambda_{B a t} & \text { Battery strategy parameter } \\ \eta_{E l e c} & \text { Efficiency of total electric propulsion system } \\ \sigma & \end{array}$

\section{Appendix A}

Airlines and aircraft manufacturers challenge the profitability of their aircraft fleet by calculating direct operating costs (DOC). The DOC model, which is implemented in the simulation tool is introduced. Each value is calculated in Euros that equal the price level of 2016. A DOC model, its main equations and values are taken from Bardenhagen and Gobbin [45]. HEA cost modifications and their values are highlighted.

\section{Appendix A.1. Total DOC}

The yearly DOC per aircraft consists of energy, crew, maintenance, capital costs, airport and ATM fees:

$$
D O C_{\text {Total,yearly }}=D O C_{\text {Energy }}+D O C_{C r e w}+D O C_{M a}+D O C_{C a p}+D O C_{F e e s}
$$


For its calculation the flight cycles (FC) per year are required. The potential yearly operating time is $8760 \mathrm{~h}$. Checks and repairs cause a yearly forced downtime of 11.4 days [63]. In the remaining 353.6 days of operation, a night curfew between 11 p.m. and 6 a.m. is valid for most airports. A regional aircraft with a flight time of approximately $85 \mathrm{~min}$, a push back \& taxi time of $20 \mathrm{~min}$ and a turn-around time of $45 \mathrm{~min}$ is able to operate six flights per day. This is consistent to the findings of Bradley and Droney [50] for the average departures of a regional aircraft. In total 2121 flight cycles can be flown with such an aircraft per year

\section{Appendix A.2. Energy}

Fuel and electricity costs are calculated taking the fuel burn (FB) in $\mathrm{kg}$, the fuel price $\left(p_{\text {Fuel }}\right)$ in EUR $/ \mathrm{kg}$, the required battery energy $\left(E_{B a t}\right)$ in $\mathrm{kWh}$ and the electricity price $\left(p_{\text {Elec }}\right)$ in EUR/kWh. The U.S. Energy Information Administration [64] publishes a yearly forecast for the energy prices. The fuel price for 2035 is predicted to be $0.934 \mathrm{USD} / \mathrm{kg}$ and the electricity price is said to be $0.114 \mathrm{USD} / \mathrm{kWh}$. A currency exchange rate of 0.87 is taken to convert US Dollars into Euros:

$$
D O C_{\text {Energy }}=0.87 F C\left(F B p_{\text {Fuel }}+E_{\text {Bat }} p_{\text {Elec }}\right)
$$

Appendix A.3. Labor

A crew consists of one flight attendant per 50 PAX and two pilots. Airlines calculate with five crew complements (CC) to operate one regional aircraft. The yearly salaries $(s)$ are EUR 70,000 per pilot $\left(n_{F C}\right)$ and EUR 30,000 per flight attendant $\left(n_{F A}\right)[45]$.

$$
D O C_{\text {Crew }}=C C\left(s_{F A} n_{F A}+s_{F C} n_{F C}\right)
$$

Appendix A.4. Maintenance

These costs are separated into airframe material $\left(D O C_{A F, m a t}\right)$ and personnel $\left(D O C_{A F, p e r}\right)$, engine $\left(D O C_{E n g}\right)$ and overall technology costs $\left(D O C_{T e c}\right)$ :

$$
D O C_{M a}=\left(D O C_{A F, m a t}+D O C_{A F, p e r}+D O C_{E n g}+D O C_{T e c}\right) F C
$$

The airframe material costs depend on the fixed airframe repair costs per flight $\left(k_{R e p}\right)$, the total block time in $\mathrm{h}$ and the airframe weight $\left(W_{A F}\right)$ in $\mathrm{kg}$ :

$$
W_{A F}=O W E-W_{\text {Prop }}
$$

With the operating weight empty $(O W E)$ and the weight of the propulsion $\left(W_{\text {Prop }}\right)$ both in $\mathrm{kg}$ :

$$
D O C_{A F, \text { mat }}=W_{A F}\left(0.0010136 t_{\text {Total }}+0.0012632\right)+k_{\text {Rep }}
$$

The personnel costs are determined with the help of labor costs $(L R)=50 \mathrm{EUR} / \mathrm{h}$ :

$$
D O C_{A F, p e r}=L R\left(\left(W_{A F} \times 10^{-4}+0.5\right) t_{\text {Total }}+\left(W_{A F} \times 10^{-4}+0.25\right)\right)
$$

A significant effort is needed for maintaining the engines of the aircraft. The related costs also depend on the sea-level thrust, which is substituted with the total maximum power rating. It occurs while takeoff and depends on the V1 velocity $(54.121 \mathrm{~m} / \mathrm{s})$ and the takeoff propulsion efficiency (0.64545) given by Nita [65]:

$$
D_{\text {Eng }}=7.621 \times 10^{-4} \frac{0.64545 P_{\text {Total,max }}}{54.121 \frac{m}{s}}+30.5 t_{\text {Total }}+10.6
$$


This equation is modified to be independent of the number of engines installed. Furthermore, Propfe et al. [23] clarify that maintenance costs for the propulsion system do not differ between a conventional and a hybrid electric system for an electric vehicle. Although the electric motors require less checks and repairs, additional expenses to maintain two different systems outweigh this advantage. Only for a full electric drive train a maintenance cost advantage of nine percent is obtained. In this DOC model the engine maintenance costs are multiplied with factor 0.91 for a $H_{P}=1$.

General technology costs for an airline to maintain their aircraft fleet are also considered. These include all fixed costs and depend on the wing span $(b)$ and the fuselage length $(l)$ of the aircraft fleet:

$$
D O C_{T e c}=5000(b \times l)^{0,75}
$$

Appendix A.5. Capital

Depreciation costs are calculated to consider the initial investment for the aircraft in a DOC model. An annuity rate is determined for the investments made depending on the depreciation rate $(D P)$, the interest rate $(I R)$ and the residual value factor $\left(f_{R V}\right)$ :

$$
a=I R \frac{1-f_{R V}\left(\frac{1}{1+I R}\right)^{D P}}{1-\left(\frac{1}{1+I R}\right)^{D P}}
$$

It will be distinguished between two annuity factors-one for the aircraft and one for the battery. The total capital costs are the sum of the costs for the aircraft $\left(D O C_{C a p, A C}\right)$ and the battery $\left(D O C_{C a p, B a t}\right)$.

Airlines take a depreciation rate of 20 years for the aircraft including the propulsion system. Thus, a residual value of $10 \%$ of the initial costs is considered [66,67]. The overall yearly capital costs for the aircraft without the batteries are determined by summing up all investments and multiplying these with the annuity factor and the insurance rate $\left(f_{\text {Ins }}\right)=0.5 \%$ :

$$
\begin{aligned}
D_{C O C_{C a}, A C} & =\left(p_{A F} W_{A F}\left(1+k_{S, A F}\right)+p_{G T} P_{G T, \max }\left(1+k_{S, G T}\right)+p_{E M} P_{E M, \max }\left(1+k_{S, E M}\right)\right. \\
& \left.+p_{P M A D}\left(\frac{P_{E M, \max }}{\eta_{E M} \eta_{P M A D}}+\frac{P_{E M, \max }}{\eta_{E M} \eta_{P M A D}^{2}}\right)\left(1+k_{S, P M A D}\right)\right) *\left(a_{A C}+f_{\text {ins }}\right)
\end{aligned}
$$

The price for the gas turbines is $551.50 \mathrm{EUR} / \mathrm{kW}$, which is derived from the USD 920,000 sales price of one PW127 M engine with a maximum power output of $2177 \mathrm{~kW}$ [68]. The airframe costs are calculated with the total list price of the ATR 72, as USD 23 Mio. [69], subtracting the engine costs. This equals EUR 1595.30 per $\mathrm{kg}$ of the airframe.

The cost aspects of the electric components are determined. Since commercialization of such high-power components is not reached, there are no sources for a reliable pricing structure. The costs are compared to the exemplary HTS projects, in which high power components were realized. Two reference values are available in the literature: a 7.5 MW HTS motor for a boat costs 46.67 EUR/kW [70] using a currency exchange rate from US Dollar (USD) to Euro (EUR) of 0.87 and a 12 MW HTS wind energy generator and its cryocooling system cost $210.25 \mathrm{EUR} / \mathrm{kW}$ [71]. Here, a higher price than the average value of these two references is taken into account due to higher certification costs in the aviation industry. Costs of $150 \mathrm{EUR} / \mathrm{kW}$ are assumed for a high-power electric motor. The costs for the power electronics are derived from the motor costs, because of lack of information. The cost ratio between power electronics and electric motors is examined for exemplary applications in an electric vehicle and a wind energy plant. Kochhan et al. [72] investigate the costs of an electric car and use a cost ratio of 0.3. In wind energy plants the power electronics have a higher share of total costs and the cost ratio is 0.713 [73]. In this paper, an average cost ratio of 0.5 is taken. This leads to power electronics costs of $75 \mathrm{EUR} / \mathrm{kW}$. Other costs for the cables and further electric components are not considered, because it is assumed that they outweigh the cost reductions that are achieved by downsizing the fuel tank system for a HEA. 
The costs of the battery systems are examined. Li-S cells material costs are projected to be around USD 70-130 per kWh. The overall battery pack costs are targeted to reach USD 150 per kWh [74].

Spare parts, which are also bought with the aircraft, are encountered with the factor $k_{S}$. As the electric components require less replacements [23], the spare parts factor is assumed to be lower for these compared to the gas turbine system.

Table A1. Overview of component prices and spare parts factors.

\begin{tabular}{cccc}
\hline Components & Price $\boldsymbol{p}$ & Spare Parts Factor $\boldsymbol{k}$ & Source \\
\hline Electric motor & EUR 150/kW & 0.2 & {$[70,71]$} \\
Inverter/converter & EUR 75/kW & 0.2 & {$[72,73]$} \\
Electric cable & Not considered & - & - \\
Battery 2 (high power Li-S) & EUR 150/kW & - & {$[74]$} \\
Airframe & $1595.30 \mathrm{EUR} / \mathrm{kg}$ & 0.1 & {$[46,69]$} \\
Gas turbine & $551.50 \mathrm{EUR} / \mathrm{kW}$ & 0.3 & {$[68]$} \\
\hline
\end{tabular}

${ }^{1}$ Assumption that costs for cable outweigh savings for smaller fuel tank system.

The battery capital costs are calculated differently. As the battery strategy is chosen to rely on ground charging, more than one battery set is needed per aircraft. The assumption is made that the battery can be used twice a day for flights due to charging times in between the operations. For six flights a day three battery sets are needed to operate the aircraft. The depreciation rate of the battery is derived with the lifetime cycles of the batteries $\left(N_{\text {Bat,cycles }}\right)$ :

$$
D P_{\text {Bat }}=3 \frac{N_{\text {Bat,cycles }}}{F C}
$$

The battery annuity can be calculated with $D P_{B a t}$ and a residual value factor of $40 \%$ [10]. In the last step, the total battery capital costs are examined:

$$
D_{C O C_{\text {Cap }, \text { Bat }}}=3 E_{\text {Bat }} p_{\text {Bat }}
$$

With the price for the battery in EUR/kWh.

The total investment costs are calculated with the sum of the two capital cost components:

$$
D O C_{C a p}=D O C_{C a p, A C}+D O C_{C a p, B a t}
$$

Appendix A.6. Fees

Airport and ATM fees are separated into landing $\left(D O C_{L d g}\right)$, ground operation $\left(D O C_{G r o u n d}\right)$ and navigation fees $\left(D O C_{N a v}\right)$ :

$$
D O C_{\text {Fees }}=D O C_{L d g}+D O C_{\text {Ground }}+D O C_{N a v}
$$

The landing fees depend on the MTOW in $\mathrm{kg}$ and the total block time $\left(t_{\text {Total }}\right)$ :

$$
D O C_{L d g}=\left(9.5 \times 10^{-3}-1 \times 10^{-3} \ln \left(t_{\text {Total }}\right)\right) M T O W \times F C
$$

Ground operation includes the costs for the turn-around process of the aircraft and the PAX handling. The calculation takes into account the payload $(P L)$ of the aircraft:

$$
D O C_{\text {Ground }}=\left(0.11 P L-5 \times 10^{-7} P L^{2}\right) F C
$$


Navigation fees are charged from ATM operators and relate to the range flown in $\mathrm{km}$, the MTOW and a navigation fee factor $\left(k_{N a v}\right)$, which depends on the type of flight:

$$
D O C_{\text {Nav }}=\left(k_{\text {Nav }} \frac{\text { Range }}{1000} \times \sqrt{\frac{M T O W}{50000}}\right) F C
$$

An average factor for European domestic flights $(850 \mathrm{EUR} / \mathrm{km})$ is chosen. The total DOC is determined applying these equations.

\section{References}

1. European Commission. Flightpath 2050-Europe's Vision for Aviation; European Commission: Luxembourg City, Luxembourg, 2011.

2. Boeing. Current Market Outlook 2016-2035; Boeing: Chicago, IL, USA, 2016.

3. Airbus. Global Market Forecast—Mapping Demand 2016/2035; Airbus: Toulouse, France, 2016.

4. Heinemann, P.; Schmidt, M.; Jeßberger, C.; Will, F.; Kaiser, S.; Hornung, M. Sizing implications of a regional aircraft for inner-city operations. Aircr. Eng. Aerosp. Technol. 2017, 89, 520-534. [CrossRef]

5. Kuhn, H.; Seitz, A.; Lorenz, L.; Isikveren, A.T.; Sizmann, A. Progress and perspectives of electric air transport. In Proceedings of the 28th Congress of the International Council of the Aeronautical Sciences ICAS, Brisbane, Australia, 23-28 September 2012; Volume 6, pp. 4886-4899.

6. Bijewitz, J.; Seitz, A.; Isikveren, A.T.; Hornung, M. Multi-Disciplinary Design Investigation of Propulsive Fuselage Aircraft Concepts. Aircr. Eng. Aerosp. Technol. 2016, 88, 257-267. [CrossRef]

7. Isikveren, A.T.; Seitz, A.; Bijewitz, J.; Mirzoyan, A.; Isyanov, A.; Grenon, R.; Atinault, O.; Godard, J.-L.; Stueckl, S. Distributed Propulsion and Ultra-high By-Pass Rotor Study at Aircraft Level. Aeronaut. J. 2015, 119, 1327-1376. [CrossRef]

8. Pornet, C.; Gologan, C.; Vratny, P.C.; Seitz, A.; Schmitz, O.; Isikveren, A.T.; Hornung, M. Methodology for Sizing and Performance Assessment of Hybrid Energy Aircraft. J. Aircr. 2014, 52, 1-12.

9. Isikveren, A.T.; Kaiser, S.; Pornet, C.; Vratny, P.C. Pre-design strategies and sizing techniques for dual-energy aircraft. Aircr. Eng. Aerosp. Technol. 2014, 86, 525-542. [CrossRef]

10. Isikveren, A.T.; Seitz, A.; Vratny, P.C.; Pornet, C.; Plötner, K.O.; Hornung, M. Conceptual studies of universally-electric systems architectures suitable for transport aircraft. In Proceedings of the Dtscher Luft-und Raumfahrt Kongress, Berlin, Germany, 10-12 September 2012.

11. Stoll, A.M.; Bevirt, J.; Moore, M.D.; Fredericks, W.J.; Borer, N.K. Drag Reduction Through Distributed Electric Propulsion. In Proceedings of the 14th AIAA Aviation Technology, Integration, and Operations Conference, Atlanta, GA, USA, 16-20 June 2014; pp. 1-10.

12. Welstead, J.; Felder, J.L. Conceptual Design of a Single-Aisle Turboelectric Commercial Transport with Fuselage Boundary Layer Ingestion. In Proceedings of the 54th AIAA Aerospace Sciences Meeting, San Diego, CA, USA, 4-8 January 2016; pp. 1-17.

13. Antcliff, K.R.; Capristan, F.M. Conceptual Design of the Parallel Electric-Gas Architecture with Synergistic Utilization Scheme (PEGASUS) Concept. In Proceedings of the 18th AIAA/ISSMO Multidisciplinary Analysis and Optimization Conference, Denver, CO, USA, 5-9 June 2017; pp. 1-15.

14. Antcliff, K.R.; Guynn, M.D.; Marien, T.V.; Wells, D.P.; Schneider, S.J.; Tong, M.J. Mission Analysis and Aircraft Sizing of a Hybrid-Electric Regional Aircraft. In Proceedings of the 54th AIAA Aerospace Sciences Meeting, San Diego, CA, USA, 4-8 January 2016; pp. 1-18.

15. Strack, M.; Chiozzotto, G.P.; Iwanizki, M.; Plohr, M.; Kuhn, M. Conceptual Design Assessment of Advanced Hybrid Electric Turboprop Aircraft Configurations. In Proceedings of the 17th AIAA Aviation Technology, Integration, and Operations Conference, Denver, CO, USA, 5-9 June 2017; pp. 1-20.

16. Van Bogaert, J. Assessment of Potential Fuel Saving Benefits of Hybrid-Electric Regional Aircraft. Master's Thesis, TU Delft, Delft, The Netherlands, 2015.

17. Stückl, S.; van Toor, J.; Lobentanzer, H. VOLTAIR-The All Electric Propulsion Concept Platform-A Vision for Atmospheric Friendly Flight. In Proceedings of the 28th International Congress of the Aeronautical Sciences, Brisbane, Australia, 23-28 September 2012; pp. 1-11.

18. Bombardier. Market Forecast 2014-2033; Bombardier: Valcourt, QC, Canada, 2014. 
19. Madavan, N.; Heidmann, J.; Bowman, C.; Kascak, P.; Jankovsky, A.; Jansen, R. A NASA Perspective on Electric Propulsion Technologies for Commercial Aviation. In Proceedings of the Workshop on Technology Roadmap for Large Electric Machines, Urbana-Champaign, IL, USA, 5-6 April 2016.

20. Moore, M.D.; Fredericks, B. Misconceptions of Electric Propulsion Aircraft and their Emergent Aviation Markets. In Proceedings of the 52nd Aerospace Sciences Meeting, AIAA SciTech Forum, National Harbor, MD, USA, 13-17 January 2014; pp. 1-17.

21. ATR Aircraft. The ATR-600 Series: The Most Economical E Ecological Way to Fly Short-Haul Connections; ATR DC/E Mark: Blagnac Cedex, France, 2008.

22. Hepperle, M. Aspects of Distributed Propulsion-A View on Regional Aircraft. In Proceedings of the Symposium Elektrisches Fliegen, Stuttgart, Germany, 18-19 February 2016.

23. Propfe, B.; Redelbach, M.; Santini, D.J.; Friedrich, H. Cost Analysis of Plug-in Hybrid Electric Vehicles including Maintenance \& Repair Costs and Resale Values. In Proceedings of the EVS26 International Battery, Hybrid and Fuel Cell Electric Vehicle Symposium, Los Angeles, CA, USA, 6-9 May 2012.

24. Hepperle, M. Electric Flight-Potential and Limitations. In Proceedings of the Energy Efficient Technologies and Concepts of Operation, Lisbon, Portugal, 22-24 October 2012.

25. Kuhn, H.; Sizmann, A. Fundamental Prerequisites for Electric Flying. In Proceedings of the Dtscher Luft-Und Raumfahrt Kongress, Berlin, Germany, 10-12 September 2012; pp. 1-8.

26. Hosking, E.; Kenny, D.P.; Mccormick, R.I.; Moustapha, S.H.; Sampath, P.; Smailys, A.A. The PW $10 O$ Engine: 20 Years of Gas Turbine Technology Evolution. In Proceedings of the RTO AVT Symposium on Design Principles and Methods for Aircraft Gas Turbine Engines, Toulouse, France, 11-15 May 1998.

27. Seitz, A.; Isikveren, A.T.; Hornung, M. Electrically Powered Aero-Propulsion Systems. In Proceedings of the 49th AIAA/ASME/SAE/ASEE Joint Propulsion Conference, San Jose, CA, USA, 15-17 July 2013; pp. 1-16.

28. Vratny, P.C.; Kuhn, H.; Hornung, M. Influences of voltage variations on electric power architectures for hybrid electric aircraft. CEAS Aeronaut. J. 2017, 8, 31-43. [CrossRef]

29. Berg, F.; Palmer, J.; Miller, P.; Husband, M.; Dodds, G. HTS electrical system for a distributed propulsion aircraft. IEEE Trans. Appl. Supercond. 2015, 25, 1-5. [CrossRef]

30. Sivasubramaniam, K.; Zhang, T.; Lokhandwalla, M.; Laskaris, E.T.; Bray, J.W.; Gerstler, B.; Shah, M.R.; Alexander, J.P. Development of a high speed HTS generator for airborne applications. IEEE Trans. Appl. Supercond. 2009, 19, 1656-1661. [CrossRef]

31. Brown, G.V. Weights and Efficiencies of Electric Components of a Turboelectric Aircraft Propulsion System. In Proceedings of the 49th AIAA Aerospace Sciences Meeting including the New Horizons Forum and Aerospace Exposition, Orlando, FL, USA, 4-7 January 2011.

32. Kim, H.D.; Felder, J.L.; Tong, M.T.; Armstrong, M. Revolutionary Aeropropulsion Concept for Sustainable Aviation: Turboelectric Distributed Propulsion. In Proceedings of the 2013 International Society for Air Breathing Engines, Busan, Korea, 9-13 September 2013.

33. Madavan, N. Hybrid-Electric and Distributed Propulsion Technologies for Large Commercial Air Transports: A NASA Perspective. Advanced Air Transport Technology Project. In Proceedings of the ISABE 2015, Phoenix, AZ, USA, 25-30 October 2015.

34. Pornet, C.; Isikveren, A.T. Conceptual design of hybrid-electric transport aircraft. Prog. Aerosp. Sci. 2015, 79, 114-135. [CrossRef]

35. Masson, P.J.; Breschi, M.; Tixador, P.; Luongo, C.A. Design of HTS axial flux motor for aircraft propulsion. IEEE Trans. Appl. Supercond. 2007, 17, 1533-1536. [CrossRef]

36. Jones, C.E.; Norman, P.J.; Galloway, S.J.; Armstrong, M.J.; Bollman, A.M. Comparison of Candidate Architectures for Future Distributed Propulsion Aircraft. IEEE Trans. Appl. Supercond. 2016, 26, 1-9. [CrossRef]

37. Masson, P.J.; Luongo, C.A. HTS machines for applications in all-electric aircraft. In Proceedings of the 2007 IEEE Power Engineering Society General Meeting, Tampa, FL, USA, 24-28 June 2007; pp. 1-6.

38. Teichel, S.H.; Dörbaum, M.; Misir, O.; Merkert, A.; Mertens, A.; Seume, J.R.; Ponick, B. Design considerations for the components of electrically powered active high-lift systems in civil aircraft. CEAS Aeronaut. J. 2014, 6, 49-67. [CrossRef]

39. Gerssen-Gondelach, S.J.; Faaij, A.P.C. Performance of batteries for electric vehicles on short and longer term. J. Power Sources 2012, 212, 111-129. [CrossRef]

40. Wild, M.; O'Neill, L.; Zhang, T.; Purkayastha, R.; Minton, G.; Marinescu, M.; Offer, G.J. Lithium sulfur batteries, a mechanistic review. Energy Environ. Sci. 2015, 8, 3477-3494. [CrossRef] 
41. Nagata, H.; Chikusa, Y. All-Solid-State Lithium-Sulfur Battery with High Energy and Power Densities at the Cell Level. Energy Technol. 2016, 4, 484-489. [CrossRef]

42. Song, M.; Zhang, Y.; Chairns, E. A long-life, high-rate lithium/sulfur cell: A multifaceted approach to enhancing cell performance. Nano Lett. 2013, 13, 5891-5899. [CrossRef] [PubMed]

43. Wang, W.; Tao, L.; Markham, J.; Zhang, Y.; Tan, E.; Batan, L.; Biddy, M.; Wang, W.; Tao, L.; Zhang, Y.; et al. Review of Biojet Fuel Conversion Technologies; NREL: Golden, CO, USA, 2016; p. 98.

44. International Energy Agency (IEA). Recent Trends in the OECD: Energy and $\mathrm{CO}_{2}$ Emissions; International Energy Agency (IEA): Paris, France, 2016.

45. Bardenhagen, A.; Gobbin, A. Flugzeugentwurf II; Universität Stuttgart: Stuttgart, Germany, 2017.

46. ATR Aircraft. ATR 72-600; ATR Aircraft: Blagnac Cedex, France, 2014.

47. Federal Aviation Administration (FAA). Part 25-Airworthiness Standards: Transport Category Airplanes Subpart B. 2017. Available online: https:/ / www.ecfr.gov / cgi-bin/text-idx?SID=caefbbc53bccf4e355983e23e3c168a6\& $m c=$ true\&node $=$ se14.1.25_1121\&rgn=div8 (accessed on 28 August 2017).

48. Gammeter, C.; Krismer, F.; Kolar, J.W. Weight and efficiency analysis of switched circuit topologies for modular power electronics in MEA. In Proceedings of the IECON 2016-42nd Annual Conference of the IEEE Industrial Electronics Society, Florence, Italy, 23-26 October 2016; pp. 3640-3647.

49. Kraytsberg, A.; Ein-Eli, Y. Review on Li-air batteries-Opportunities, limitations and perspective. J. Power Sources 2011, 196, 886-893. [CrossRef]

50. Bradley, M.K.; Droney, C.K. Subsonic Ultra Green Subsonic Ultra Green Aircraft Research: Phase I Final Report; Technical Report; Boeing Research and Technology: Huntington Beach, CA, USA, 2011.

51. Liu, Y.; Elham, A.; Horst, P.; Hepperle, M. Exploring vehicle level benefits of revolutionary technology progress via aircraft design and optimization. Energies 2018, 11, 166. [CrossRef]

52. Westphal, C.W.; Heinze, W.; Horst, P. Multidisciplinary Integrated Preliminary Design Applied to Unconventional Aircraft Configuration. J. Aircr. 2008, 45, 581-592. [CrossRef]

53. Risse, K.; Anton, E.; Lammering, T.; Franz, K.; Hoernschemeyer, R. An integrated environment for preliminary aircraft design and optimization. In Proceedings of the 53rd AIAA/ASME/ASCE/AHS/ASC Structures, Structural Dynamics and Materials Conference, Honolulu, HI, USA, 23-26 April 2012.

54. Botero, E.; Wendorff, A.D.; MacDonald, T.; Variyar, A.; Vegh, J.M.; Lukaczyk, T.W.; Alonso, J.J.; Orra, T.H.; Ilario da Silva, C.R. SUAVE: An Open-Source Environment for Multi-Fidelity Conceptual Vehicle Design. In Proceedings of the 54th AIAA Aerospace Sciences Meeting: American Institute of Aeronautics and Astronautics (AIAA SciTech Forum), San Diego, CA, USA, 4-8 January 2016; pp. 1-16.

55. Greitzer, E.M.; Bonnefoy, P.A.; delaRosaBlanco, E.; Dorbian, C.S.; Drela, M.; Hall, D.K.; Hansman, R.J.; Hileman, J.I.; Liebeck, R.H.; Lovegren, J. N + 3 Aircraft Concept Designs and Trade Studies, Final Report Structures, Weight, and Thermodynamic Cycles; Rep. CR-2010-216794; NASA: Hampton, VA, USA, 2010.

56. Howe, D. Aircraft Conceptual Design Synthesis; John Wiley \& Sons: Chichester, UK, 2000.

57. Kurzke, J. GasTurb 12-Design and Off-Design Performance of Gas Turbines. 2012. Manual. Available online: http:/ / www.gasturb.de/manual.html (accessed on 2 December 2017).

58. ATR Aircraft. ATR Family; ATR Aircraft: Blagnac Cedex, France, 2014.

59. Obert, E.; Slingerland, R.; Leusink, D.J.W.; van den Berg, T.; Koning, J.H.; van Tooren, M.J.L. Aerodynamic Design of Transport Aircraft; IOS Press: Amsterdam, The Netherlands, 2009.

60. Young, K.; Wang, C.; Wang, L.Y.; Strunz, K. Electric Vehicle Integration into Modern Power Networks; Springer: New York, NY, USA, 2013.

61. Kato, Y.; Hori, S.; Saito, T.; Suzuki, K.; Hirayama, M.; Mitsui, A.; Yonemura, M.; Iba, H.; Kanno, R. High-power all-solid-state batteries using sulfide superionic conductors. Nat. Energy 2016, 1, 16030. [CrossRef]

62. McConnachie, D.; Wollersheim, C.; Hansman, R.J. The Impact of Fuel Price on Airline Fuel Efficiency and Operations. In Proceedings of the 2013 Aviation Technology, Integration, and Operations Conference, Los Angeles, CA, USA, 12-14 August 2013; pp. 1-14.

63. Franz, K. CeRAS Direct Operating Cost (DOC) Model. 2014. Available online: http:/ / ceras.ilr.rwth-aachen. de/trac/wiki/CeRAS/ToolsAndMethodologies/DOC. (accessed on 2 December 2017).

64. EIA. Annual Energy Outlook 2017. U.S. Energy Information Administration, 2017. Available online: https:/ / www.eia.gov / outlooks/aeo/data/browser/\#/?id=12-aeo2017\&cases=ref2017 ref_no_cpp\&sourcekey=0 (accessed on 30 August 2017). 
65. Nita, M.F. Aircraft Design Studies Based on the ATR 72; Hamburg University of Applied Sciences: Hamburg, Germany, 2008.

66. Ali, S.; Hampson, N. Aviation Finance-Fasten Your Seatbelts. Available online: https://www.pwc.com/im/ en/publications / assets / shipping-aircraft-space/pwc-aviation-finance-fastern-your-seat-belts-pdf.pdf (accessed on 30 August 2017).

67. Lufthansa Group. Geschäftsbericht 2016; Lufthansa Group: Cologne, Germany, 2016.

68. Forecast International. The Market for Aviation Turboprop Engines; Forecast International: Newtown, CT, USA, 2010.

69. The Flying Engineer. Proud to Fly a Turboprop: Q400 vs. ATR72. Available online: http://theflyingengineer. com/aircraft/proud-to-fly-a-turboprop-q400-vs-atr72/ (accessed on 30 August 2017).

70. Schiff, N.; Schiferl, R. Latest Developments in Superconducting Motors. 2000. Available online: http: //www.machinedesign.com/motorsdrives/latest-developments-superconducting-motors (accessed on 30 August 2017).

71. Sung, H.-J.; Park, M.; Go, B.-S.; Yu, I.-K. A study on the required performance of a 2G HTS wire for HTS wind power generators. Supercond. Sci. Technol. 2016, 29, 54001. [CrossRef]

72. Kochhan, R.; Fuchs, S.; Reuter, B.; Burda, P.; Matz, S.; Lienkamp, M. An Overview of Costs for Vehicle Components, Fuels and Greenhouse Gas Emissions; Technische Universität München, Fakultät für Maschinenwesen, Lehrstuhl für Fahrzeugtechnik: Garching, Germany, 2014; pp. 1-19.

73. Blanco, M.I. The economics of wind energy. Renew. Sustain. Energy Rev. 2009, 13, 1372-1382. [CrossRef]

74. Hagen, M.; Hanselmann, D.; Ahlbrecht, K.; Maça, R.; Gerber, D.; Tübke, J. Lithium-Sulfur Cells: The Gap between the State-of-the-Art and the Requirements for High Energy Battery Cells. Adv. Energy Mater. $2015,5$. [CrossRef]

(C) 2018 by the authors. Licensee MDPI, Basel, Switzerland. This article is an open access article distributed under the terms and conditions of the Creative Commons Attribution (CC BY) license (http:/ / creativecommons.org/licenses/by/4.0/). 